\title{
Evaluation of Biological Conversion of Coal-Derived Synthesis Gas
}

\section{Topical Report}

\author{
R.K. Fu \\ G. Mazzella
}

September 1990

Work Perforned Under Contract No.: DE-AC21-86MC23077

For

U.S. Department of Energy

Office of Fossil Energy

Morgantown Energy Technology Center

Morgantown, West Virginia

By

Foster Wheeler USA Corporation

Clinton, New Jersey

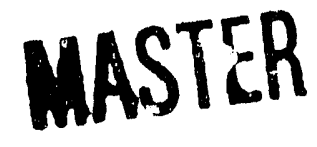




\section{DISCLAIMER}

This report was prepared as an account of work sponsored by an agency of the United States Government. Neither the United States Government nor any agency thereof, nor any of their employees makes any warranty, express of implied, or assumes any legal liability or responsibility for the accuracy, completeness or usefulness of any information, apparatus, product, or process disclosed, or represents that its use would not infringe privately owned rights. Reference herein to any specific commercial product, process, or service by trade name, trademark, manufacturer, or otherwise, does not necessarily constitute or imply its endorsement, recommendation, or favoring by the United States Government or any agency thereof. The views and opinions of authors expressed herein do not necessarily state or reflect those of the United States Government or any agency thereof.

'i his report has been reproduced directly from the best available copy.

Available to DOE and DOE contractors from the Office of Scientific and Technical Information, P.O. Box 62, Oak Ridge, TN 37831; prices available from (615)576-8401, FTS 626-8401.

Available to the public from the National Technical Information Service, U.S. Department of Commerce, 5285 Port Royal Rd., Springfield, VA 22161. 
EVALUATION OF BIOLOGICAL CONVERSION

OF COAL-DERIVED SYNTHESIS GAS

TABLE OF CONTENTS

PAGE NO.

1.0 SUMMARY 1

2.0 SCOPE OF STUDY

3.0 BASIS FOR CONCEPTUAL DESIGNS

3.1 CONVENTIONAL COAL-BASED SNG PLANT 8

3.2 SYNGAS BIOCONV'RSION 8

$\begin{array}{lll}4.0 & \text { CONVENTIONAL COAL-BASED SNG PLANT } & 14\end{array}$

4.1 PLANT DESCRIPTION 1.4

4.2 MASS AND ENERGY BALANCES 20

4.3 OPERATING SUMMARY 20

4.4 ESTIMATED CAPITAL COSTS 22

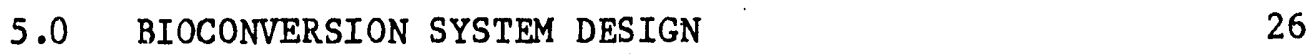

5.1 SYSTEM DESCRIPTION 26

5.2 HEAT AND MATFILIAL BALANCES 32

5.3 OPERATING REYUIREMENTS 32

5.4 ESTIMATED CAPITAL COSTS 40

6.0 INIEGRATED BIOCONVERSION SNG PLANT 41

6.1 PLANT DESCRIPTION 41

6.2 MASS AND ENERGY BALANCES 45

6.3 OPERATING SUMMARY 45

6.4 ESTIMATED CAPITAL COSTS 47

$\begin{array}{lll}7.0 & \text { ECONOMIC EVALUATION } & 54\end{array}$

7.1 ECONOMIC GUIDELINES $\quad 54$

7.2 ANNUAL OPERATING COSTS 55

7.3 LEVELIZED SNG COST 55

7.4 EFFECT OF PURCHASED ACETIC ACID 55

7.5 EFFECT OF SNG PRODUCT SPECIFICATIONS

$4190 Y$ 
TABLE OF CONTENTS (Cont' $d$ )

PAGE NO.

$\begin{array}{ll}\text { 8.0 CONCLUSIONS AND RECOMMENDATIONS } & 60\end{array}$

8.1 BIOCONVERSION FOR SNG PRODUCTION 60

8.2 BIOCONVERSION FOR HYDROGEN PRODUCTION 62

9.0 LITERATURE REFERENCES 63 


\subsection{SUMMARY}

Foster Wheeler USA Corporation conducted an evaluation study on the blological conversion of synthesis gas to methane which is under development at the University of Arkansas. A conceptual design of an Integrated coal-based SNG plant, employing the bloconversion process route, was developed together with the corresponding capital and operating costs. The economics were compared to those for a coal-based SNG plant design using the conventional catalytic route for shift and methanation.

The design basis for the bloconversion unit was established in confunction with the University of Arkansas. A two-stage bioconversion route to methane was selected using a tri-culture consisting of $P$. productus, R. rubrum, and $M$. formlclcum. Foster wheeler developed the conceptual process design for the overall bioconversion unit which comprised the following three subsystems:

\section{- Acetate Production \\ - Shift/Methanation \\ - Medium Preparation}

The bioconversion unit design was incorporated into an integrated SNG plant design, having a nominal capacity of 125 billion Btu/day of SNG produced from Pittsburgh No. 8 bituminous coal. The performance and costs for the conventional coal-based SNG plant were extracted from a prevlous GRI study (2). Overall plant performances for the conventional catalytic route and the bioconversion processing scheme are compared in Table 1.1. Of particular significance are the higher coal and water usages for the bloconversion route. These are directly related to the lack of steam generation via waste heat recovery and the rejection of reaction heat to cooling water in the bioconversion process which operates at about $100^{\circ} \mathrm{F}$. Consequently, the annual operating costs for the SNG plant based on bioconversion of syngas are about $8 \%$ higher than for the conventional catalytic design, as shown below:

\begin{tabular}{lcc} 
& $\begin{array}{c}\text { Conventional } \\
\text { Design }\end{array}$ & $\begin{array}{c}\text { Bioconversion } \\
\text { Design }\end{array}$ \\
\cline { 2 - 3 } Coal Cost, \$MM & 99.4 & 110.6 \\
Variable O\&M Cost, \$MM & 64.3 & 64.6 \\
By-Product Cred1t, \$MM & $\underline{(7.4)}$ & $\underline{(6.6)}$ \\
Net Annual Cost, MM\$ & 156.3 & 168.6
\end{tabular}

Based on the conceptual plant design, an estimate of the total plant investment was developed for the integrated bloconversion SNG plant. Thi.3 estimate reflects mid-1985 costs for a Western Pennsylvania site. 
TABLE 1.1

INT BGRATED SNG PLANT PERFORMANCE

\begin{tabular}{|c|c|c|}
\hline & $\begin{array}{c}\text { Conventional } \\
\text { Route } \\
\end{array}$ & $\begin{array}{c}\begin{array}{c}\text { Bloconversion } \\
\text { Rout:e }\end{array} \\
\end{array}$ \\
\hline \multirow[t]{2}{*}{$\begin{array}{l}\text { Coal Feed, TPD } \\
\text { Gasification } \\
\text { Steam Generation }\end{array}$} & $\begin{array}{r}7,780 \\
0 \\
\end{array}$ & $\begin{array}{r}7,780 \\
875 \\
\end{array}$ \\
\hline & 7,780 & 8,655 \\
\hline Limestone, TPD & 0 & 207 \\
\hline Raw Water, GPM & 3,054 & 5,175 \\
\hline Catalyst and Chemicals, \$/Day & 14,250 & 2,149 \\
\hline $\begin{aligned} \text { SNG Product, MMSCFD } \\
\mathrm{HHV}, \mathrm{Btu} / \mathrm{SCF}\end{aligned}$ & $\begin{array}{r}131.6 \\
950\end{array}$ & $\begin{array}{r}129.3 \\
950\end{array}$ \\
\hline $\begin{array}{l}\text { By-Products: } \\
\text { Sulfur, TPD } \\
\text { Amoonia, TPD }\end{array}$ & $\begin{array}{r}179 \\
30\end{array}$ & $\begin{array}{r}165 \\
22\end{array}$ \\
\hline Sollds to Disposal, TPD & 1,409 & 1,725 \\
\hline Cold Gas Efficlency, \% & 68.0 & 60.1 \\
\hline
\end{tabular}


In addition to the facilities construction costs, the total plant investment includes allowances for project contingency, initial catalyst and chemical charges, process royalties, and start-up costs. As summarized in Table 1.2, the total plant investment for the bloconversion design is about $4 \%$ higher than for the conventional catalytic route. Major cost factors which account for this difference are the cost for the bloconversion unit in the processing facilities and the need for auxlllary steam generation in the support systems.

The higher operating and capital costs for the bloconversion plant design result in a levelized cost of SNG of $\$ 7.1 / \mathrm{MMB}$ tu compared to $\$ 6.6 / \mathrm{MMB}$ tu for the conventional catalytic route. Under these conditions, bloconversion of synthesis gas for SNG production is clearly not competitive with the conventional catalytic process for shift and methanation.

Further development of the bioconversion process could possibly improve the relative economics for SNG production. Areas recomended for future $R \& D$ effort include the following:

- Develop bacterlal cultures for simultaneous sulfur removal.

- Develop an Improved strain of mlcroorganism for shift conversion which will allow higher cell concentrations and higher operating temperatures.

- Improve the bioreactor design for shlft/methanation to allow for more efficlent heat removal. 
TABLE 1.2

SNG PLANT INVESTMENT SUMMARY

BASIS: MID-1985

Conventional Route

Process FCI*

Support FCI*

Project Contingency

Engineering and Design Cost.

Total FCI*

Inftial Catalyst Inventory

Pald-up Royalty

Start-up Cost

Total Plant Investment, \$MM
353

263

616

92

96

804

15

6

65

890
Bloconversion Route

364.5

286.7

651.2

97.7

$\underline{101.1}$

850.0

1.3

6.0

65.0

922.3

* Facilities Construction Investment. 
As part of the technical support services provided for the DOE/GRI Joint Coal Gasification Research Program, Foster Wheeler conducted an evaluation study on the biological conversion of coal-derived synthesis gas for SNG production. The objertive of this study was to determine the potentlal technical and economic advantages of the bioconversion technology which is being developed by the Untversity of Arkansas.

A block flow dlagram illustrating the conceptual bloconversion route to SNG is shown in Figure 2.1. In this concept, the bioconversion unit essentially replaces the conventional. catalytic processing steps for shift conversion and methanation. In conducting the evaluation study, Foster Wheeler developed conceptual designs and costs estimates for Integrated coal-to-SNG plants based on the bioconversion route as well as the conventional catalytic processing scheme. Levelized costs for the SNG product were calculated and the relative economics for the bloconversion route were assessed with respect to the process design assumptions used. In addition, technilal areas where future research efforts should be directed to realize any potential benefits of the bioconversion technology were identifled.

In performing this evaluation, use of design and cost information from previous studies on coal-to-SNG plants was maximized. Accordingly, Foster Wheeler's efforts were primarily concerned with developing the conceptual design and costs for the bloconversion processing units and the assoclated support systems, such as culture preparation. The design basis and processing scheme for the bloconversion syster was established by Foster wheeler in conjunction with the University of Arkansas.

The following subtasks outline the overall scope of Foster Wheeler's study effort:

\subsection{Conventional Plant Design and Cost Estimate}

Based on previous design studies, a biock flow diagram of the integrated SNG plant will be developed, together with the overall plant operating requirements. Capital costs for the Individual process units and support systems w11l be scaled and updated, as required, from previous work.

\subsection{Bloconversion Design Basis}

Foster Wueeler w111 review the avallable reports on the Unf versity of Arkansas' technology for blological conversion of synthesis gas to methane. This information, together with additional discussions with the University of Arkansas, will be used to establish a basis for the conceptual design relative to: 


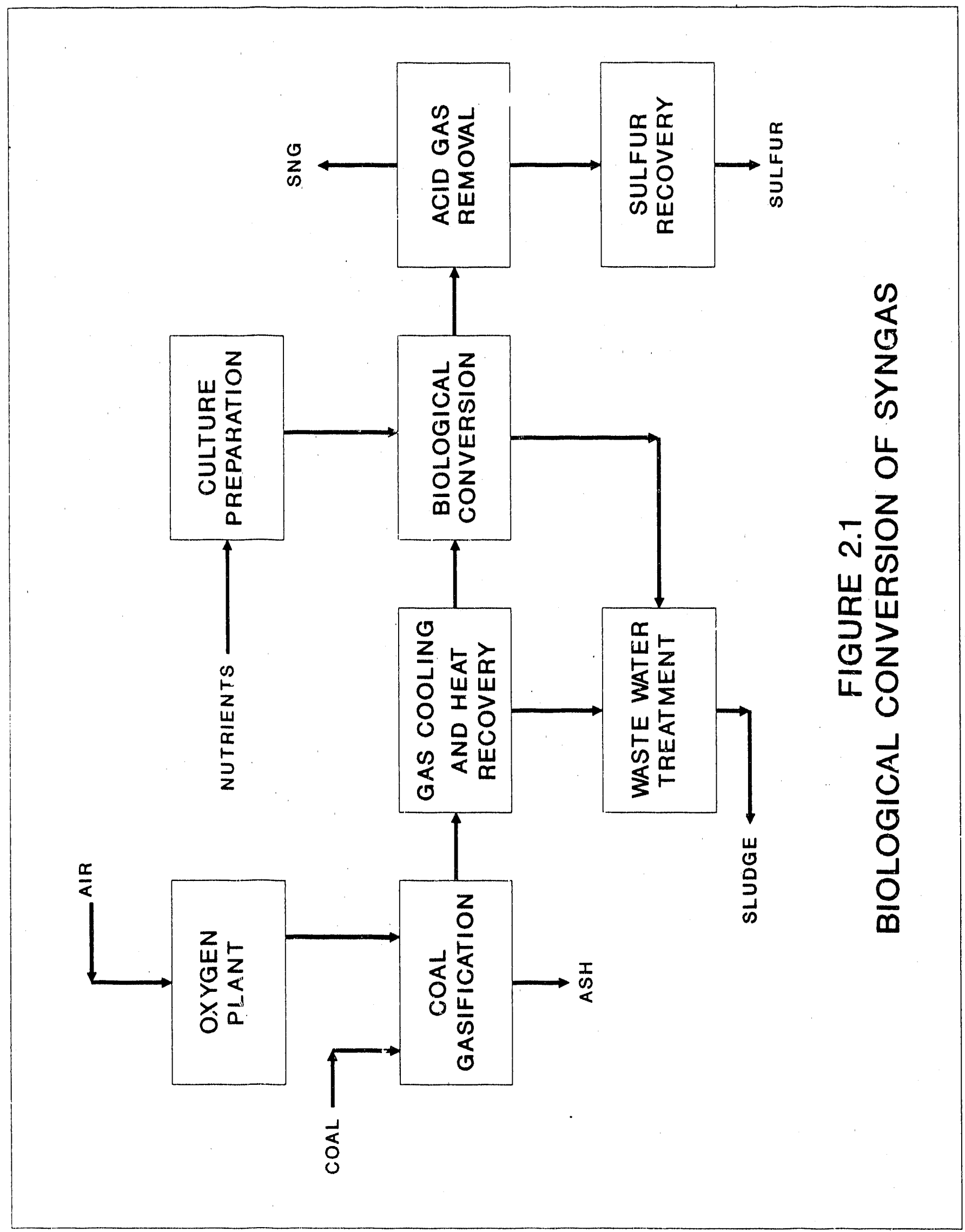


- Selection of micro-organisms and appropriate operating conditions.

- The processing sequence required for a bloconversion system.

- Reaction rates, ylelds, and reactor design for comerclal application.

\subsection{Biloconversion System Design}

Conceptual designs for the bioconversion units and support systems w111 be developed in accordance with the established design basis. These designs will include process flow diagrams, heat and material balances, major equipment sizes, and operating requirements.

\subsection{Integrated Plant Design and Cost Estimate}

Block tlow diagram of the coal-to-SNG plant scheme which incorporates the bloconversion route will be prepared. The bioconversion units will be integrated into the overall plant scheme and the corresponding operating requirements will be summarized. Foster Wheeler will develop capital cost estimates for the bloconverston process units based on major equipment costs. The overall plant cost will be developed from the Individual process units costs which will be factored, as necessary, from the conventional plant costs.

\subsection{Economic Assessment}

Based on the estimated capital costs and operating requirements, the levelized cost for SNG will be calculated for both the conventional coal-tr-SNG plant and the bloconversion process route. Sensitivity analyses relative to key design assumptions for the bloconversion proces 8 will be made.

\subsection{Summary Report}

Foster Wheeler will prepare a topical report summarizing the results of the evaluation study. The report will include a discussion of the design assumptions and potentlal for the bloconversion technology, as well as recommendations for future $R \& D$ areas. 


\subsection{BASIS FOR CONCEPTUAL DESIGNS}

\subsection{Integrated Coal-Based SNG Plant}

The integrated plant has a nominal design capacity of 125 billion BTU per day of SNG product. The plant is self-contalned except for coal, raw water, and consumable catalysts and chemlcals. Product SNG specifications, as given in Table 3.1, follow GRI's guidelines (1).

The plant is assumed to be located in Western Pennsylvanla adjacent to the coal mine from which the plant feed is obtalned. Pittsburgh No. 8 bltuminous coal is the design feedstock, having characteristics as shown in Table 3.2. Coal crushed to less than six 1r.ches is recelved via conveyor at the plant battery $11 \mathrm{mits}$ on a six days per week and two shift per day basis. Storage and handling facilities are provided for 14 days of live coal storage and 30 days in dead storage. The plant site is assumed to have an adequate water supply so that water cooled exchangers are used for all steam turbine surface condensers and for most cooling services below $140^{\circ} \mathrm{F}$.

The conceptual plant designs for SNG production are based on KRW fluidized-bed gasification of coal in an oxygen-blown mode without in-bed sulfur capture. The conventional design case, employing catalytic shift and methanation, was extracted from a previous GRI study (2). Plant equipment is spared as necessary to achleve a $90 \%$ service factor and multiple tralns are provided for all major processing units.

\subsection{Syngas Bloconversion}

Blological conversion of coal-derived synthesis gas to methane is based on the process technology belng developed at the University of Arkansas. Accordingly, the design basis for the bloconversion unit, as employed in this study, was established in confunction with the University of Arkansas via Foster Wheeler's review of pertinent project reports (3-5) and subsequent discussions with the research associates at the University.

The design basis which evolved from this effort represented an extrapolation of the UnIversity of Arkansas' experimental data towards commerclal operating conditions. The block flow diagram in Figure 3.1 11lustrates the commerclal process concept for the bloconversion unit as established for this study. This system consists of two reaction stages employing a tri-culture of $P$. productus, $R$. rubrum, and $M$. formictcum to convert carbon monoxide and hydrogen into methane. In the first stage, $a$ small portion of the syngas feed is processed to produce acetic acid which is needed for culture growth in the second stage bloreactor. Carbon monoxide is converted to acetic acld by the $P$. productus anaerobe according to the following reaction:

$$
4 \mathrm{CO}(\mathrm{g})+2 \mathrm{H}_{2} \mathrm{O}(1) \longrightarrow \mathrm{CH}_{3} \mathrm{COOH}(1)+2 \mathrm{CO}_{2}(\mathrm{~g})
$$


TABLE 3.1

\section{PRODUCT SNG SPECIFICATIONS}

- Interchangeability

Criterld for acceptahility:

$\begin{array}{lll}\text { Lifting Index }\left(I_{L}\right) & 1.06 & \text { maximum } \\ \text { Flash-Back Index }\left(I_{F}\right) & 1.20 & \text { maximum } \\ \text { Yellow TIp Index }\left(I_{Y}\right) & 0.90 & \text { minimum }\end{array}$

- Composition

\section{MaxImum}

Carbon Wozoxicie

$0.1 \%$ rol.

Hydrogen sulfide

Total Sulfur

Water

0.25 grains/100 SCF

10 gralns/100 SCR

7 1bs/MASCF

- Heating Value

Measured at 14.7 pola and $60^{\circ} \mathrm{F}$ : $950 \mathrm{BTU}$ ( HHV)/SCF

- Delivery Pressure

Pressire $\quad 1000$ ps 18 
TABLE 3.2

COAL CHARACTERISTISS

GE VERAL DESCRIPTION

\author{
Rank \\ Coal seam \\ Mining Method \\ Preparation
}

\author{
Bituminous \\ P1tts burgh No. 8 \\ Underground \\ Run of Mine
}

\section{PROPERTIES}

$\begin{array}{lr}\text { Proximate Analysis, as recelved, Wt\% } & \\ \text { Molsture } & 12.0 \\ \text { Volatile Matter } & 34.0 \\ \text { Fised Carbon } & 45.2 \\ \text { Ash } & 8.8 \\ & 100.0 \\ & \\ \text { Ultimate Analysis, dry, Wt: } & \\ \text { Carbon } & 74.30 \\ \text { Hydrogen } & 5.18 \\ \text { Nitrogen } & 1.50 \\ \text { Oxygen } & 6.10 \\ \text { Sulfur } & 2.90 \\ \text { Ash } & 9.90 \\ \text { Chlorine } & 0.12 \\ & 100.00\end{array}$

Heating Value of Coal, As Recelved $\mathrm{BTU} / 1 \mathrm{~b}$ ( HHV) $\quad 11,870$

Heating Value of Dry coal, BTU/1b (HHV) 13,490

Porm of Sulfur as \% of Total Sulfur Pyritic

Sulfate

1

Organtc

47

$\frac{47}{100}$

Hardgrove Grindabillty Index 


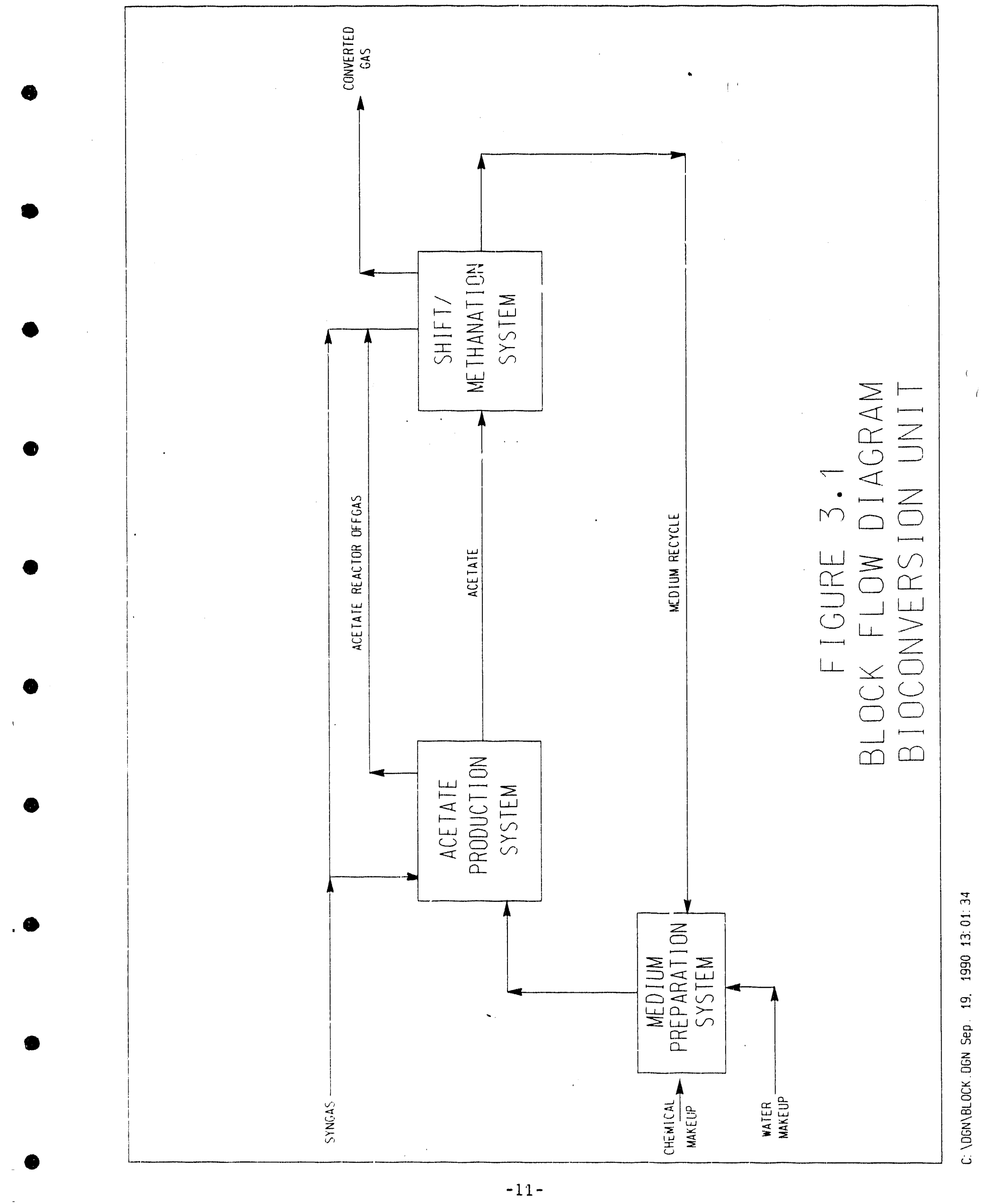


The second stage employs a co-culture of $R$. rubrum and $M$. forlcicum for combined shift and methanation of the remaining syngas feed, 1.e.

$$
\begin{gathered}
\mathrm{CO}(\mathrm{g})+\mathrm{H}_{2} \mathrm{O}(\mathrm{I}) \longrightarrow \mathrm{H}_{2}(\mathrm{~g})+\mathrm{CO}_{2}(\mathrm{~g}) \\
4 \mathrm{H}_{2}(\mathrm{~g})+\mathrm{CO}_{2}(\mathrm{~g}) \longrightarrow \mathrm{CH}_{4}(\mathrm{~g})+2 \mathrm{H}_{2} \mathrm{O}(1)
\end{gathered}
$$

For the nominal production of 125 billion BTU per day of SNG, the bloconversion uilt was designed to process 52,244 1b-mols/hr of synthesis' gas having the following composition:

\begin{tabular}{lc} 
& Mo1\% \\
\cline { 2 - 2 } $\mathrm{CO}$ & 47.19 \\
$\mathrm{H}_{2}$ & 33.81 \\
$\mathrm{CO}_{2}$ & 11.15 \\
$\mathrm{CH}_{4}$ & 6.29 \\
$\mathrm{~N}_{2}+\mathrm{A}$ & 0.54 \\
$\mathrm{NH}_{3}$ & - \\
$\mathrm{H}_{2} \mathrm{~S}$ & 0.81 \\
$\mathrm{COS}$ & 0.06 \\
$\mathrm{H}_{2} \mathrm{O}$ & 0.15 \\
& 100.00
\end{tabular}

The design bases for the first and second stages of bloconversion, as established with the University of Arkansas, are summarized in Table 3.3. 
TABLE 3.3

\section{BIOCONVERSION DESIGN BASIS}

\begin{tabular}{|c|c|c|}
\hline Reaction Stage & cetate Production & Shift $\frac{\text { Second }}{\& \text { Methanation }}$ \\
\hline Culture Type & - Productus & R. Rubrum \& M. Formictcum \\
\hline Reactor Type & CSTR & Cocurrent Packed Column \\
\hline $\begin{array}{c}\text { Operating Temperature, }{ }^{\circ} \mathrm{F} \\
\text { Pressure, psia }\end{array}$ & $\begin{array}{l}100 \\
425\end{array}$ & $\begin{array}{l}100 \\
415\end{array}$ \\
\hline Syngas Feed, \% & 2.0 & 98.0 \\
\hline Conversion, $\begin{array}{r}\mathrm{CO} \% \\
\mathrm{H}_{2} \%\end{array}$ & 90 & $\begin{array}{l}99.2 \\
98.5\end{array}$ \\
\hline Cell Concentration, $\mathrm{gm} / 1$ iter & 50 & 120 \\
\hline Agitation Power, $\mathrm{HP} / \mathrm{ft}^{3}$ & 0.23 & - \\
\hline No. Reactors & 2 & 10 \\
\hline Reactor Volume, $\mathrm{ft}^{3}$ & 2,120 & 13,620 \\
\hline Gas Residence TIme, min & 0.62 & 0.04 \\
\hline \multicolumn{3}{|l|}{ Net Heat of Reaction } \\
\hline $\mathrm{BTU} / 1 \mathrm{~b}$-mole CO & - & +990 \\
\hline $\mathrm{BTU} / 1 \mathrm{~b}-\mathrm{mole} \mathrm{CH}_{4}$ & - & $-47,900$ \\
\hline $\mathrm{BTU} / 1 \mathrm{~b}-\mathrm{mol} \mathrm{CH}_{3} \mathrm{COOH}$ & $-44,100$ & - \\
\hline
\end{tabular}




\subsection{CONVENTIONAL COAL-BASED SNG PLANT}

The conceptual design for the conventional coal-based SNG plant, employlng catalytic shift and methanation, was extracted from an earlier GRI study (2) on coal gasification for SNG production. This plant is designed to produce 132 MMSCFD of SNG product, having a higher lieating value of 950 BTU/SCF, from P1ttsburgh No. 8 bitiminous coal.

\subsection{Plant Description}

A block flow dlagram of the conventional coal-based SNG plant is shown in Figure 4.1. The grassroots plant design consists of the following processing units.

100 - Coal Preparation

Coal from live storage is conveyed to roll crushers where the size is reduced to minus 2 inches. The crushed cnal is then conveyed to the coal Drying and Grindi: nit.

$\underline{150-C o a l ~ D r y 1 n g ~ a n d ~ G r i n d i n g ~}$

Minus 2 inch coal is fed to fmpact mills where it is ground in the presence of hot nitrogen sweep gas. The product coal is minus $1 / 4$ inch with no more than $10 \%$ smaller than 100 mesh. The molsture content of the coal feed 18 reduced from $12 \%$ in the as-recelved coal to $7 \%$. The coal Drying and Grinding unit is designed for two operating trains plus one spare train.

$200-$ Gasification and Quench

This section consists of seven KRW fluldized-bed gasification trains ( 6 operating and one spare) using $99.5 \%$ oxygen as the oxidant. Ifnus $1 / 4$ inch coal is fed to the gasifiers via a lockhopper system pressurized with $\mathrm{CO}_{2}$. Coal, steam, and oxygen react in the gasifier at about $1900^{\circ} \mathrm{F}$ and 450 psla to produce a raw syngas stream. Syngas leaving the gasifier contains fine particulates which are removed in a cyclone separator and recycled to extinction in the gasifier.

Ash from the gasifier continuously enters the ash recelving hopper which operates at the gasifier pressure. The removal of ash a dry agglomerates allow for disposal without additional processing steps and minimizes the overall water usage in the KRW gasification system.

The raw product gas is cooled from $1875^{\circ} \mathrm{F}$ to $420^{\circ} \mathrm{F}$ in a heat recovery system which preheats boller feed water and generates superheated steam at $1500 \mathrm{psia}$ and $950^{\circ} \mathrm{F}$. Finally, the product gas is quenched to saturated conditions and trace particulates are removed ty scrubbing with water. 


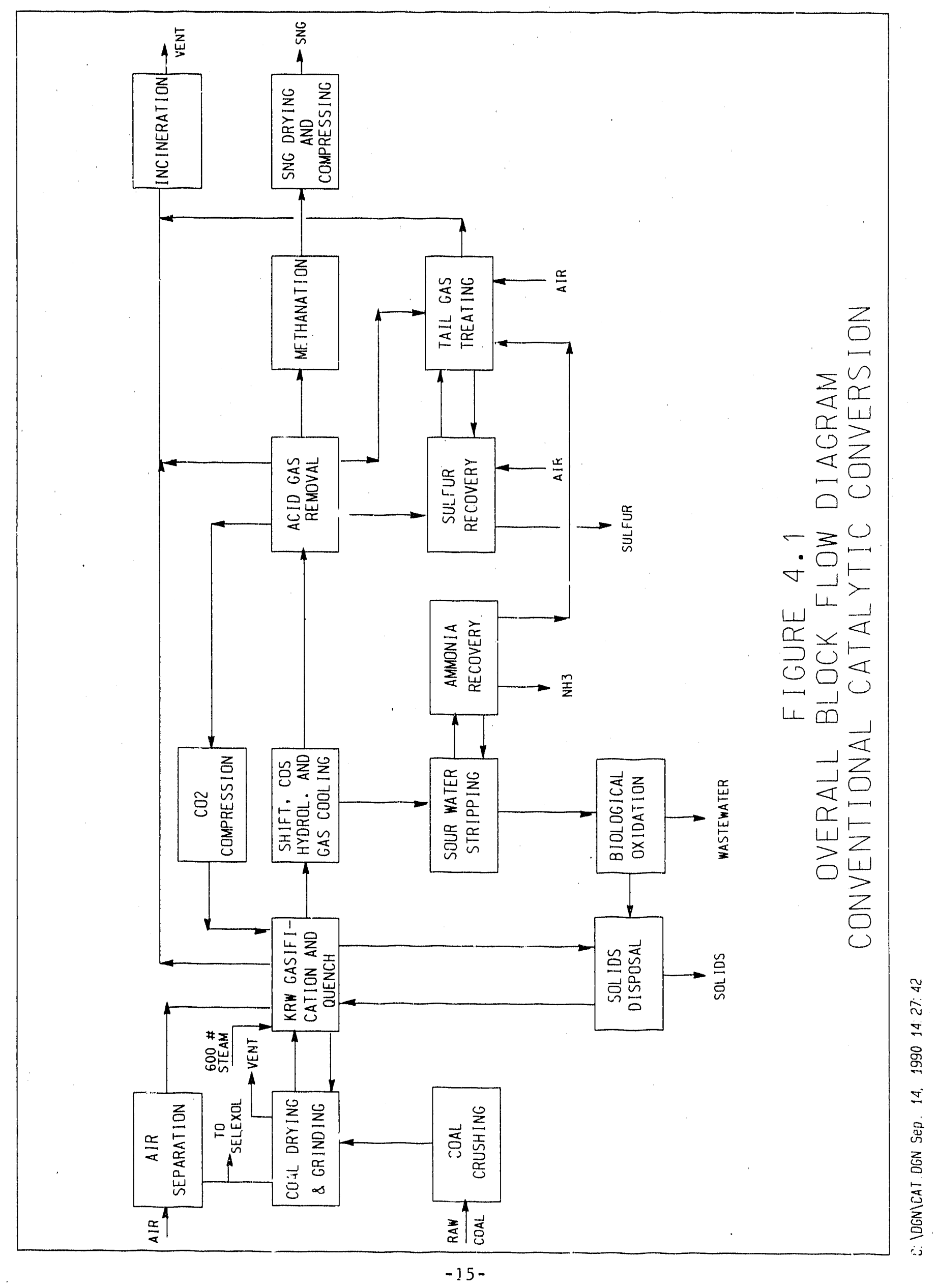


This process unit, designed as two 50\% trains, produces a syngas with a $\mathrm{H}_{2} / \mathrm{CO}$ ratio of 3.2 and a $\mathrm{COS}$ content less than $72 \mathrm{ppm}$. The ad justment in $\mathrm{H}_{2} / \mathrm{CO}$ ratio is required for methane synthesis, while COS hydrolysis facilitates sulfur compound removal in the Acid Gas Removal Unit.

Raw gas from gasification is preheated to $450^{\circ} \mathrm{F}$ by exchange with shift converter effluent gas. Approximately 82 percent of the preheated gas flows to the shift converters. Saturated $600 \mathrm{psig}$ steam is added to the shift converter feed gas to obtain a steam/dry gas ratio of 0.30 in the shift converter effluent. The reactions occurring over the shift converter's cobalt-molybdenum catalysts are:

$$
\begin{aligned}
& \mathrm{CO}+\mathrm{H}_{2} \mathrm{O} \longrightarrow \mathrm{CO}_{2}+\mathrm{H}_{2} \\
& \mathrm{COS}+\mathrm{H}_{2} \mathrm{O} \longrightarrow \mathrm{CO}_{2}+\mathrm{H}_{2} \mathrm{~S}
\end{aligned}
$$

Heat is recovered from the shift converter effluent by generating 600 psig saturated steam and by preheating shift converter feed. Couled shift converter effluent is mixed with effluent from the coS hydrolysis reactors.

Approximately 18 percent of the preheated raw gas flows to the COS hydrolyst.s reactors. Haldor Topsoe's CKA catalyst, which is a spectally activated alumina, is used in these reactors. The reaction occurring over the cos hydrolysis catalyst is:

$$
\mathrm{COS}+\mathrm{H}_{2} \mathrm{O} \rightarrow \mathrm{CO}_{2}+\mathrm{H}_{2} \mathrm{~S}
$$

Effluent from the cos hydrolysis reactors and cooled effluent from the shift converters are combined. Heat recovered from the combined gas is used to heat feedwater, deaerator feedwater and make-up water to gasification. Following heat recovery, the gas is cooled to $95^{\circ} \mathrm{F}$ in air and water coolers.

\section{0 - Acid Gas Removal}

The AcId Gas Removal unit uses the Selexo]. process for selective removal of $\mathrm{H}_{2} \mathrm{~S}$ and $\mathrm{CO}_{2}$ from the syngas stream. Two $50 \%$ trains are provided; each train consists of an $\mathrm{H}_{2} \mathrm{~S}$ remova' section and a $\mathrm{CO}_{2}$ removal section.

Shifted syngas is processed in the $\mathrm{H}_{2} \mathrm{~S}$ removal section where $\mathrm{H}_{2} \mathrm{~S}$ is selectively absorbed into a lean solvent. The $\mathrm{H}_{2} \mathrm{~S}$ concentration in the absorber overhead stream is reduced to about $6 \mathrm{ppmv}$. $\mathrm{H}_{2} \mathrm{~S}-\mathrm{r} 1 \mathrm{ch}$ solvent is sent to a rebolled stripper where actd gases are recovered and sent to the Claus sulfur recovery system. 
Syngas from the $\mathrm{H}_{2} \mathrm{~S}$ absorber is sent to the $\mathrm{CO}_{2}$ removal section where the $\mathrm{CO}_{2}$ concentration is reduced to $1.1 \%$ by volume. The $\mathrm{CO}_{2}$-rich solvent from the low pressure flash flows to the $\mathrm{CO}_{2}$ stripper where nitrogen gas from the Air Separation Unit is used to strip $\mathrm{CO}_{2}$ from the solvent. The sicripper overhead gas and a portion of the low pressure vapur are incinerated in a catalytic incinerator to combust hydrocarbons and to convert trace sulfur compounds to sulfir dioxide. The regenerated solvent is recycled to the $\mathrm{CO}_{2}$ absorber.

\section{0 - Metharation}

The Methanation Unit converts sweet. gas from the Acld Gas Removal Unit to methane by the following exuthermic reactions:

$$
\begin{gathered}
\mathrm{CO}+3 \mathrm{H}_{2} \rightarrow \mathrm{CH}_{4}+\mathrm{H}_{2} \mathrm{O} \\
\mathrm{CO}_{2}+4 \mathrm{H}_{2} \rightarrow \mathrm{CH}_{4}+2 \mathrm{H}_{2} \mathrm{O}
\end{gathered}
$$

Two 50 percent methanation trains are provided. In each train there are three catalytic reaction stages, each having two parallel fixed catalyst beds sized for 25 percent of plart capacity.

Swee: gas from the Acld Gas Removal unit is preheated and passed through zinc oxide beds to remove trace amounts of sulfur. The desulfurized feed is split so that $55 \%$ flows to the first stage methanators and $45 \%$ flows to the second-stage reactors. Methanated gas from the third-stage reactors is recycled to the first-stage reactors in order to $11 \mathrm{mit}$ the adjabatic temperature rise.

Effluent gas streams from the first and second stage reactors are cooled by generating $600 \mathrm{psig}$ and $1500 \mathrm{psig}$ saturated steam. The third-stage product gas is first cooled by generating 600 psig steam and preheating feed gas to the unit. The product gas is then cooled to $95^{\circ} \mathrm{F}$ in air and water cooled exchangers.

600 - Drying and Compression

In this unit, the methanated gas is dehydrated in a glycol dehydration system and compressed to $1000 \mathrm{psig}$. The molsture content of the product SNG is reduced to less than $7 \mathrm{lb} / \mathrm{MMSCF}$ by contacting the gas with a regenerated glycol stream in a packed column. Two 50\% drying and compression trains are provided.

\section{0 - Claus Sulfur Recovery}

The sulfur plant is a two-stage, split-flow type claus unlt and two $100 \%$ trains are provided. Actual sulfur recovery per pass in the Claus unit is about $93.6 \%$. Unrecovered sulfur is sent to the tall gas treating unit where the sulfur is recovered as $\mathrm{H}_{2} \mathrm{~S}$ and recycled back to the Claus plant. Overall sulfur recovery of the combined Claus plus tall gas treating units is $99.8 \%$ of the sulfur in the fresh feed to the claus unit. 
In the sulfur recovery unit, $\mathrm{H}_{2} \mathrm{~S}$ and $\mathrm{SO}_{2}$ react ir the two converter stages to produce elemented sulfur:

$$
2 \mathrm{H}_{2} \mathrm{~S}+\mathrm{SO}_{2} \rightarrow 3 \mathrm{~S}+2 \mathrm{H}_{2} \mathrm{O}
$$

The reaction is carried out over fixed beds of alumina catalyst. Molten sulfur is condensed from the converter effluent stream via generating 60 psig steam. The tall gas at $325^{\circ} \mathrm{F}$ which contalns sulfur compounds, mainly $\mathrm{H}_{2} \mathrm{~S}$ with some $\mathrm{SO}_{2}, \mathrm{COS}$, and elemental sulfur, flows to the SCOT tall gas treating unit.

850 - Ta11 Gas Treating

The Shell Claus off-gas Treating (SCOT) process is used to remove sulfur compounds from Cla'ds plant tall gas and Ammonia Recovery Unit acld gas. One operating train is provided. A spare train is not included for the short perfods of time the SCOT Unit is not avallable, because the tail gas can bypass the SCOT Unit and go directly to the Vent Gas Incinerator.

The SCOT process is designed to remove $\mathrm{H}_{2} \mathrm{~S}$ from atmospheric pressure effluent gas streams. Because the SCOT solvent is not suitable for handling gas streams that contain substantial amounts of $\mathrm{SO}_{2}, \mathrm{COS}$, and elemental sulfur, these compounds are first catalytically converted to $\mathrm{H}_{2} \mathrm{~S}$. The reactions occur over a cobalt-molvbdenum catalyst in the presence of hydrogen and steam.

A feed gas hydrogen content 1.5 percent in excess of the stoichiometric demand is suffletent to convert essentially all sulfur compounds to $\mathrm{H}_{2} \mathrm{~S}$, with the exception of some residual (perhaps $50 \mathrm{ppmv}$ ) COS. The tail gas stream does not contain enough hydrogen or carbon monoxide to react with the varlous sulfur compounds. Therefore, a small amount of sweet gas from the Acid Gas Removal Unlt supplies the necessary hydrogen and carbon monoxide. The sweet gas is partially combusted in a reducing gas generator and thon mixed with the tail gas stream.

The effluent from the hydrogenator is cooled and then treated in an amine absorption tower where essentially all of the $\mathrm{H}_{2} \mathrm{~S}$ is removed, with only a small amount of $\mathrm{CO}_{2}$ belng coabsorbed. Treated gas, containing about $270 \mathrm{ppmv}$ total sulfur, is sent to the vent gas incinerator. Rich amine solution is regenerated in a rebolled stripper and the overhead acid gas stream is recycled back to the Claus plant for recovery of sulfur.

900 - Sour Water Strtpping

Two 50 percent sour water strtppers remove $\mathrm{H}_{2} \mathrm{~S}, \mathrm{CO}_{2}$ and $\mathrm{NH}_{3}$ from the plant sour water streams. Sour waters from the Gasification and Quench Unit, Shift and Gas Cooling Unit, and SCOT Ta11 Gas Treating Unit comprise the total feed to this unit. 
The plant: sour water streams are combined and preheated agalnst sour water stilpper bottoms and fed to the sour water stripper. In the stripper, dissolved gases are stripped from the water ising a steam heated reboller. The vapor leaving the strlpper flows to the ammonia absorber in the Ammonia Recovery Unit. The strlpper bottoms are cocled against the stripper feed prior to flowing to the Blological oxidation Unit for final treating or back to the Gasification and Quench Unit as makeup.

\section{0 - Ammonia Recovery}

The Ammonia Recovery Unit utilizes the Phosam-W process for recovering ammonia from sour water strlpper overhead gas. Two 50 percent ammonia resovery trains are provided. Sour water stripper overhead gas is contacted with an ammonia-lean phosphorlc acid solution in an absorber. The ammonla-free gas flows to the SCOT Tall Gas Treating Unit while the ammonia-rich absorber bottoms is regenerated in a steam-rebolled stripper. The steam-rebolled fractionator column produces 99.5 percent pure liquid ammonia which is pumped to storage. The water removed from the bottom of the fractionator is recycled to the sour water stripper.

\section{Support Fac1lities}

The grassroots SNG plant is also proviaed with all the necessary offsite units and support systems to supply utilities, meet environmental regulations, and inaintain plant operation. These systems include the following:

$$
\begin{array}{ll}
1000- & \text { Alr Separation } \\
1100- & \text { Blological Oxidation } \\
2000- & \text { Steam Generation } \\
2100- & \text { Power Generation } \\
2200- & \text { Solids Disposal } \\
2300- & \text { Plant Water System } \\
2400- & \text { Waste Water Evaporation } \\
2500- & \text { Coal Recelving \& Storage } \\
2600- & \text { Cooling Water System } \\
2700- & \text { Vent Gas Incinerator } \\
2800- & \text { General Facilitles }
\end{array}
$$

The general plant facliftles Include the raw water system, product storage, bulldings, electric power distribution, site preparation, fire water system, and interconnecting piping. 


\subsection{Mass and Energv Balances}

The overal1 mass and energy balances for the conventional coal-based SNG plant are summarlzed in Table 4.1. Accordingly, the cold gas effictency for this plant is about $68 \%$.

\subsection{Operating Summary}

The cual-based SNG plant is designed as a grassroots facility such that only coal, raw water, and consumable catalyst and chemicals are supplied frota external sources. The plant steam, electric power, and cooling water requirements are all satisfied internally. Overall plant performance is summarized as follows:

$\begin{array}{cc}\text { Coal Feed, TPD (as recelved) } & 7,780 \\ \text { Raw Water, GPM } & 3,054 \\ \text { SNG Product, MMSCFD } & 131.6 \\ \text { BTU ( HHV)/SCF } & 950 \\ \text { Volume \% } & 92.66 \\ \mathrm{CH}_{4} & 4.45 \\ \mathrm{H}_{2} & 0.01 \\ \mathrm{CO}^{2} & 0.80 \\ \mathrm{CO}_{2} & 2.07 \\ \mathrm{~N}_{2}+\mathrm{A} & 0.01 \\ \mathrm{H}_{2} \mathrm{O} & 100.00 \\ & 179 \\ \text { By-Products: Sulfur, TPD } & 30 \\ \text { Ammonia, TPD } & 1,409 \\ \text { Sollds to Disposa1, TPD } & 14,250 \\ \text { Catalyst \& Chemicals, \$/Day }\end{array}$

The SNG product is delivered at $95^{\circ} \mathrm{F}$ and $1000 \mathrm{psig}$ and meets the criterla for acceptablilty as df.fined in the GRI guidelines (1).

There are no coal-fired bollers in this plant design. During normal operation, high pressure superheated steam is generated via heat recovery systems in the gasification and methanation units. This steam is sufficlent to satisfy all the plant requirements.

The total plant electric power requirement is approxlmately $17.6 \mathrm{MW}$ which is generated on-site via steam turbine generators. Electric power requirements are minimized by driving all large compressors and pumps with steam turbines.

Water cooled exchangers are used for all steam turbine surface condensers and for most coollng services below $140^{\circ} \mathrm{F}$. The plant cooling water system has a circulation rate of $115,150 \mathrm{gpm}$ which corresponds to a heat removal duty of $1370 \mathrm{MMBTU} / \mathrm{HR}$. 
TAEILE 4.1

OVERALL MASS AND 'LNERGY BALANCES

CONVENTIONAL SNG PLANT

INPUT $\quad \underline{\mathrm{LB} / \mathrm{HR}}$

As received Coal Oxygen to Gasifiers Combustion Air Ni trogen Raw water Tota 1
MMBTU/HR

\begin{tabular}{rr}
648,244 & 7698.8 \\
381,818 & 20.3 \\
203,098 & 2.0 \\
448,293 & 7.3 \\
$1,526,804$ & - \\
\hline $3,208,257$ & 7728.4
\end{tabular}

$$
\begin{array}{r}
230,095 \\
14,884 \\
2,458 \\
1,564,986 \\
18,293
\end{array}
$$$$
\text { Water Losses }
$$$$
\text { Cooling Tower Loss }
$$$$
\text { Steam System Loss }
$$$$
\text { Solids to Disposal }
$$$$
\text { Air Cooling \& Misc. }
$$
Total
5233.6

58.1

22.5

63.3

$-$

1369.4

1.6 272.0

707.9 $\frac{707.9}{7728.4}$ 


\subsection{Estimated Capital Costs}

Capital cost estimates for the coal-based SNG plant were based on mid-1985 dollars for a plant location 1ri Western Pennsylvania. The estimates include a single project contingency to allow for uncertalnties in technical definition and estimating techniques. No process development allowance has been included since the design is assumed to be based on mature technology.

The facilities construction costs for the processing unfts and support systems are summarized in Tables 4.2 and 4.3 , respectively. The estimated total capital investment is detalled in Table 4.4 . 
TABLE 4.2

CONVENTIONAL COAL-BASED SNG PLANT

ESTIMATED PROCESSING FACILITIES COST

Basts: Mid-1985

Plant Section
$1100 \quad$ Coal Preparation
$200 \quad$ Gasification and Quench
$300 \quad$ Shift and Gas Cooling
$400 \quad$ Acid Gas Removal
$500 \quad$ Methanation
$600 \quad$ SNG Drying and Compression
$700 \quad$ CO 2 Compression
$800 \quad$ Claus Sulfur Recovery
$850 \quad$ Tall Gas Treating
$900 \quad$ Sour Water Strlpplng
$950 \quad$ Ammonia Recovery

No.

Trains

Base FCI $\$ M M$

$2+1$

26

$6+1$

185

2

13

2

60

2

37

2

8

2

4

$1+1$

7

1

5

2

4

2

$-4$

353

* Facilities Construction Investment 
TABLE 4.3

CONIENTIONAL COAL-BASED SNG PLANT

ESTIMATED SUPPORT FACILITIES COST

Basis: Mid-1985

\begin{tabular}{llcc} 
& Plant Section & No. & $\begin{array}{c}\text { Base FCI } \\
\text { \$MM }\end{array}$ \\
\cline { 2 - 3 } 1000 & Alr Separation & Trains & 86 \\
1100 & Blological Oxidation & 2 & 11 \\
2000 & Steam Generation & 1 & 23 \\
2100 & Power Generation & 2 & 8 \\
2200 & Sollds Disposal & 2 & 8 \\
2300 & Plant Water System & 2 & 2 \\
2400 & Waste Waier Evaporation & 2 & 4 \\
2500 & Coal Recelving and Storage & 2 & 15 \\
2600 & Cooling Water System & $1+1$ & 5 \\
2700 & Vent Gas Incinerator & 1 & 9 \\
2800 & General Facilities & 2 & 92 \\
\hline & Total Support FCI* & 2 & 263
\end{tabular}

* Facilities Construction Investment 
TABLE 4.4

CONVENTIONAL COAL-BASED SNG PLANT

SUMMARY OF CAPITAL COSTS

Bas1s: Mid-1985

Processing Facilities Cost

353

Support Facllities Cosi

263

Project Contingency $15 \%$

92

Direct FCI*

708

Englneering \& Design Cost @ 13.5\%

96

Total FCI*

804

Inftial Catalyst Inventory

15

Paid-up Royalty

6

Start-up Cost

65

Total Plant Investment

890

Working Capital:

Coal Inventory

Materfals \& Supplies

Spare Parts

Land

12.0

7.2

7.1

$\frac{1.0}{27.3}$

* Facilities Construction Investment 


\subsection{System Description}

The bioconversion system design used for this study is based on the work carried out at the University of Arkansas by Dr. J. L. Gaddy and assoctates. The design, as it is presently concelved, consists of three subsystems. The 1nterrelationshlp of the three subsystem is shown on the block flow diagram in Figure 5.1. The princlpal subsystem is the shift/methanation system where a majority of the raw synthesis gas is converted to methane using a co-culture of $R$. rubrum and $M$. formiclcum. The co-cultures are grown on beds of packing in packed colum reactors.

A small amount of synthesis gas is converted to acetate which is needed for the growth of $R$. rubrum cells. Acetate is produced in the acetate production subsystem using a pure culture of $P$. productus in continuous stirred tank reactors. Acetate produced in the reactors and retained in the culture media is separated, with the culture medium, from the $P$. productus cells. The acetate/medium solution is fed to the shift/methanation reactors to furnish the needed nutrients and minerals for the growth of $R$. rubrum and $M$. formiclcum. The nutrient and mineral requirements are very small and are used in very dilute concentrations. The culture medium is prepared, sterilized, and cooled in the medium preparation subsystem. Detalled descriptions of the three systems are given below.

\section{Acetate Production Subsystem}

The process flow diagram for this subsystem is shown in Figure 5.2 . About $2 \%$ of the cooled raw gas produced from coal gasiflcation is fed to the acetate production subsystem which consists of two parallel trains. In each train, there is a single 2120 cubic feet mechanically agitated reactor. Cooled raw gas at $85^{\circ} \mathrm{F}$ and 408 psig is fed to the reactor through a sparger located below the agitator 1mpeller near the bottom of the reactor. A 500 horsepower electric motor driven agitator is provided. The intensive agitation breaks up the gas bubbles in the slurry solution to help dissolution of the gas. Agltation also provides turbulence to remove the product from the microorganlsm as 1 t 1 produced to minimize local bulld-up of product concentration. Excessive product concentration inhibits the conversion reaction (4). In the reactor, $90 \%$ of the CO, dissolved in the solution, is reacted with water to produce acetic acid and $\mathrm{CO}_{2}$. The overall reaction is represented by the following equation:

$$
4 \mathrm{CO}(\mathrm{g})+2 \mathrm{H}_{2} \mathrm{O}(1) \rightarrow \mathrm{CH}_{3} \mathrm{COOH}(1)+2 \mathrm{CO}_{2}(\mathrm{~g})
$$

This reaction is exothermic and the estimated heat of reaction at $100^{\circ} \mathrm{F}$ is 101,900 BTU per pound mol of acetic acid produced. Energles consumed by the m1croorganism for growth and for maintenance are estimated to be 


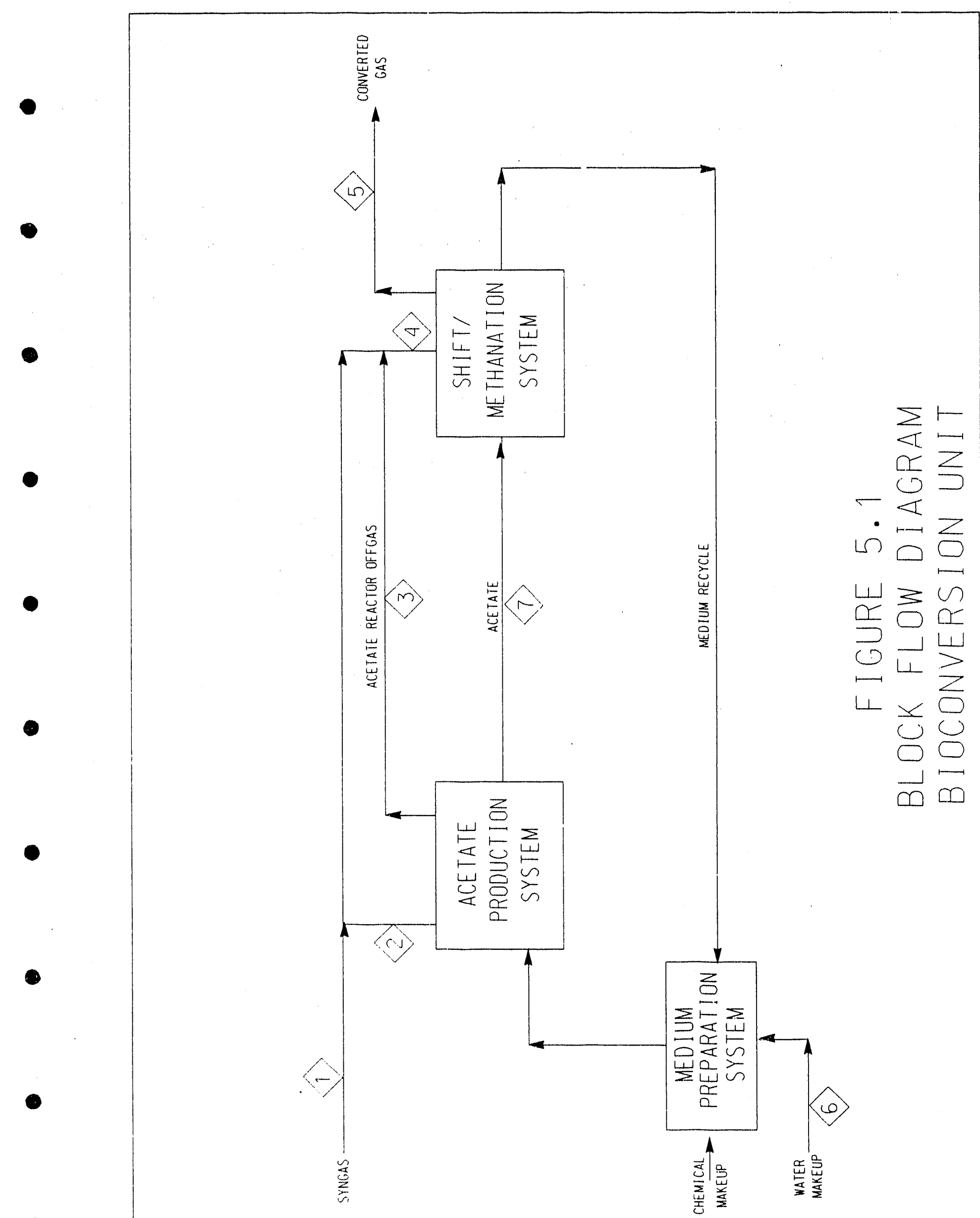




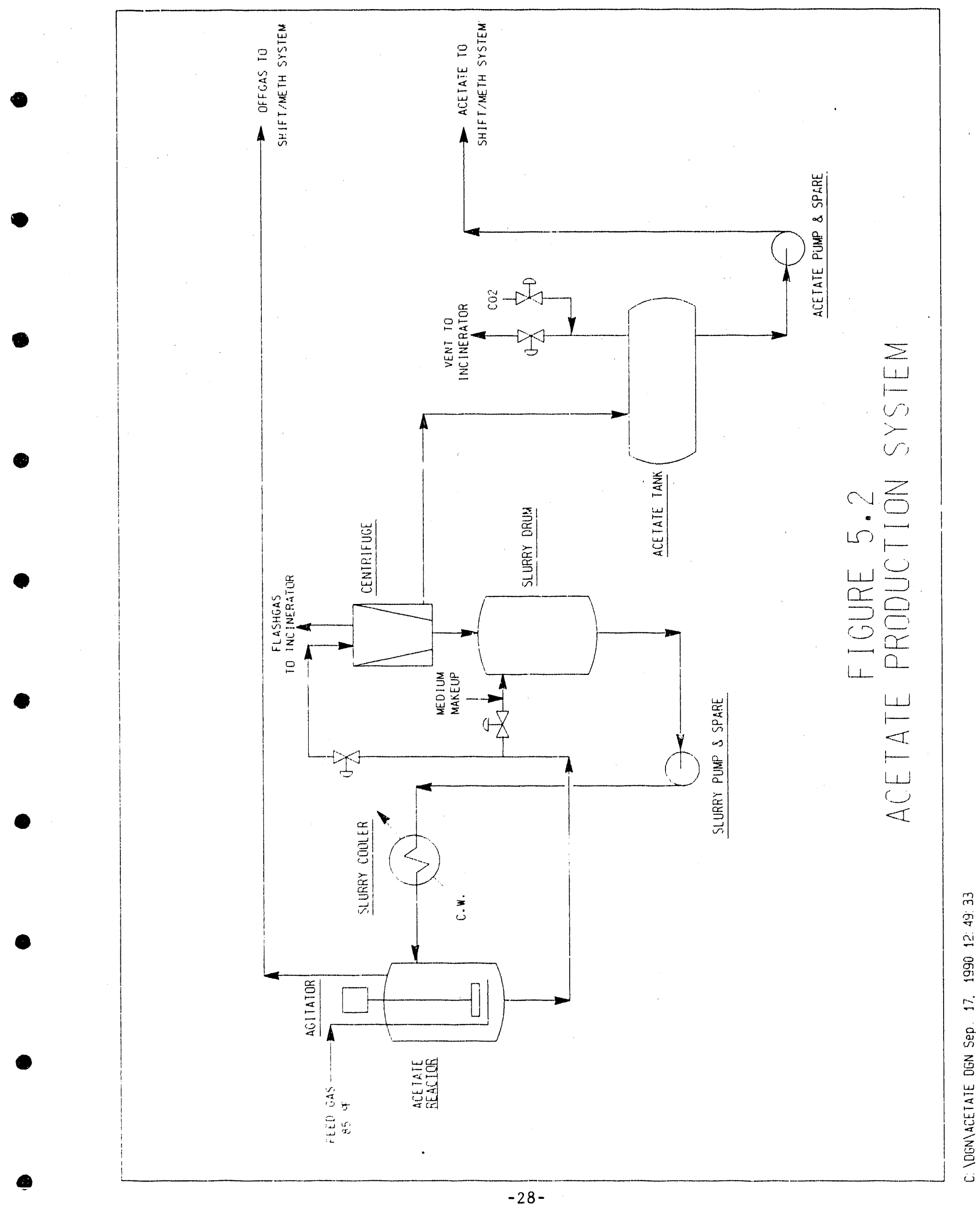


39,800 and 18,000 BTU per pound mol of acetic acld produced, respectively. This results in a net heat release from the above reaction of $44,100 \mathrm{BTU}$ per pound mol of acetic acid produced.

The reactor operates at $408 \mathrm{psig}$ inlet gas pressure and at temperatures between 90 to $100^{\circ} \mathrm{F}$. The slurry solution containing the product acetic acld and $P$. pruductus cells is removed from the reactor at pressure and Is letdown to $315 \mathrm{psig}$ to feed a vert1cal Super-D-Canter type pressurized centrifuge. The centrifuge is comerclaily avallable at a design pressure of 350 psig. The centrifuge extracts about $40 \%$ of the solution from the slurry, representing the minimum liquid removal rate needed to prevent excessive product bulldup in the solution which can Inhibit the conversion reaction. The extracted acetate/medium solution is stored in the Acetate Tank which provides 5 minutes of storoge capacity and from which it is pumped to the Shift/Methanation subsystem.

The balance of the solution from the centrifuge, along with a11 the $P$. productus cells, is discharged into the Slurry Drum. Makeup medium solution is also added to the slurry drum. Slurry in the drum is pumped back to the reactor through a cooler. The cooler removes essentially all. the heat liberated from the reaction to malntain the reactor operating temperature. The minimum slurry flow through the cooler is $470 \mathrm{gpm}$ representing the flow needed for reaction heat removal while limiting the maximum solution temperature rise across the reactor to $10^{\circ} \mathrm{F}$. It has been assumed that two percent of the $P$. productus cells in the circulating slurry are destroyed by attrition or by naturai rauses. This assumption, coupled with the assumed cell growth rate, limits the maximum slurry circulation rate to $540 \mathrm{gpm}$. The dead cells are expected to lyse and give back the chemicals and minerals used for cell growth. Tnis is the reason why there is essentlaily no chemlcals and minerals makeup requirement except for Incldental leakages and 1osses. Unreacted gas, as well as $\mathrm{CO}_{2}$ produced from the reaction, leaves from the top of the reactor and is mixed with the main gas stream which is sent to the Shlft/Methanation reactors,

\section{Shift/Methanation Subsystem}

The process flow dlagram for this subsyster is shown in Figure 5.3. Cooled raw syngas plus all the offgas from the acetate production subsystem are fed to the shift/methanation subsystem which consists of ten parallel tralns. There is a packed column reactor in each train with a clrculating pump and a solution cooler. Each packed column reactor inas five beds packed with $3^{\prime \prime}$ ceramlc Rasch!3 rings. The packings are supported by grid type packing supports. Liquid feed to the top of each packed section is distributed using a triggh type distributor Liquid is also added to the upper four packed beds in each reactor at two other elevations through plpe distributers. Liquid from each packed bed is collected at the botiom of the bed and trapped out using a chimney tray type collector. The chlmney tray allows gas to pass through to the next 


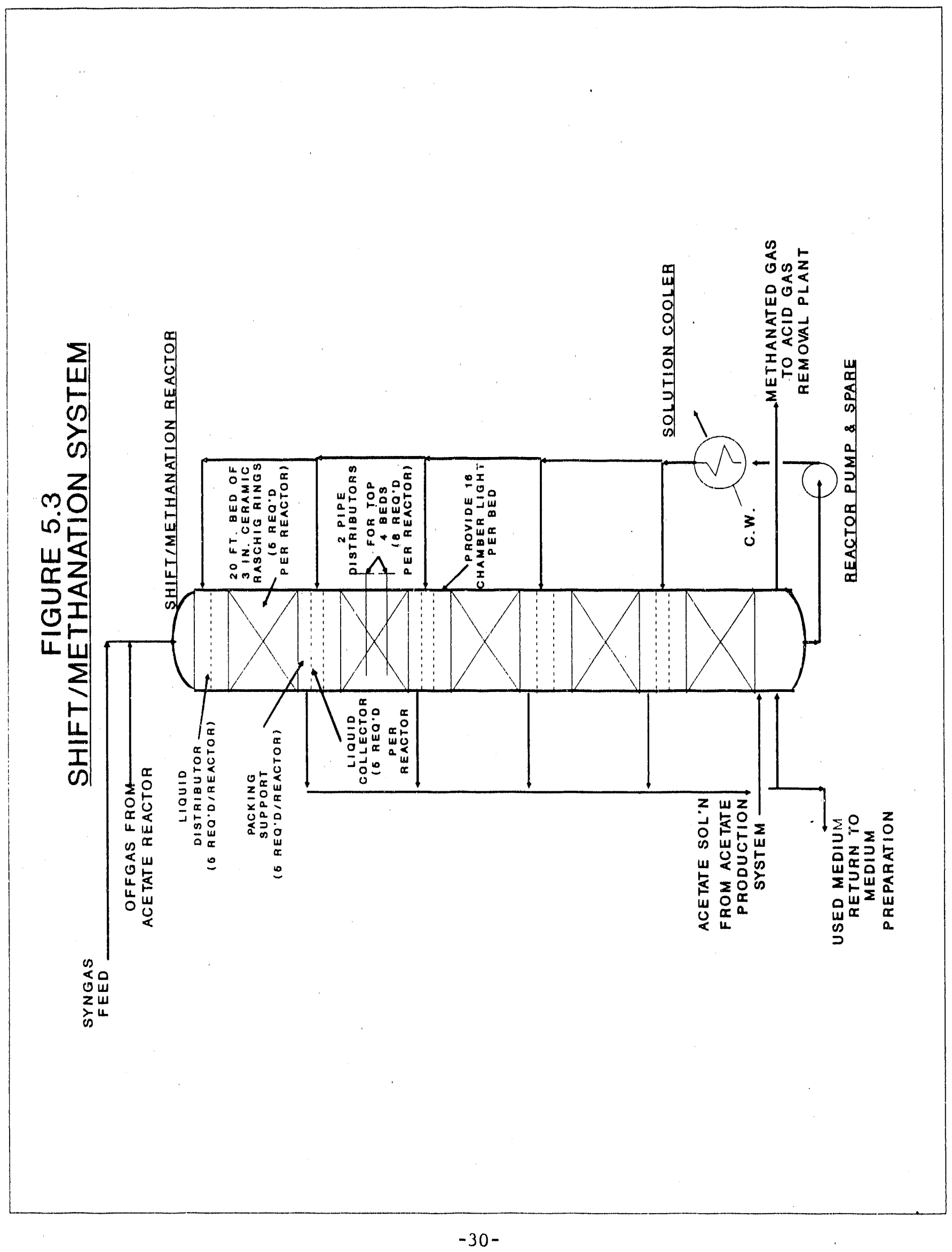


packed section and prevents 1iquid flow to the nexi bed. The liquid trapped out is allowed to drain into the liquid sump located at the bottom of the packed colum rnactor. Acetate/medium solution from the acetate production subsystem is also added to the liquid sump.

The solution in the sump is circulated through a cooler back to the column through various addition points under flow control. The flow rates are predetermined to limit the amount of $\mathrm{CO}$ dissolved in the 1lquid, especially for the upper four beds where co concentration in the gas is high. The conversion of $C O$ to hydrogen by $R$. rubrum and conversion of $\mathrm{CO}_{2}$ to $\mathrm{CH}_{4}$ by $\mathrm{M}$. formicisum are both inhibited by high Co concentrations in the solution. This inhibition effectively reduces the usefulness of the reactor volume provided (4).

Feed gas enters the reactor at the top and flows co-currently with the liquid down through the packed section in a trickle bed fashion. The co-culture microorganisms are grown on the packing thereby allowing high cell concentrations as in immobilized cell reactors. Gas flows downward through the five sections of packing in series and is separated from the liquid below the fifth bed and removed from the column. Inside the column, dissolved $\mathrm{CO}$ reacts with water to form $\mathrm{CO}_{2}$ and $\mathrm{H}_{2}$ by the shift reaction:

$$
\mathrm{CO}(\mathrm{g})+\mathrm{H}_{2} \mathrm{O}(\mathrm{I}) \rightarrow \mathrm{CO}_{2}(\mathrm{~g})+\mathrm{H}_{2}(\mathrm{~g})
$$

For this study, $R$. rubrum is used to carryout the shift reaction in the presence of a carbon source other than $C O$ and tungsten 11ght. The carbon source provided is the acetate which is produced in the acetate production subsystem. The amount of acetate required for $R$. rubrum cell production $(0.374 \mathrm{gm} R$. rubrum cell produced per gm of acetic acid consumed), the useful 11 fe of $R$. rubrum cell ( 7 days), and the hourly conversion of $C O$ to $H_{2}$ by the living $R$. rubrum cell ( 0.055 gm-mol CO converted per gm of $R$. rubrum cell) have all been determined by experimentation at the University of Arkansas ( 4,5$)$. S1xteen PressureChamber-Ilght has been provided for each packed bed to transmit the 11ght required for $R$. rubrum cell growth. The liquid-phase shift reaction is estimated to be slightly endothermic with a reaction heat requirement of 990 BTU per pound mol of CO converted.

Hydrogen formed by the shift reaction, as well as dissolved hydrogen, reacts with $\mathrm{CO}_{2}$ in the solution to form methane by the methanation reaction:

$$
\mathrm{CO}_{2}(\mathrm{~g})+4 \mathrm{H}_{2}(\mathrm{~g}) \rightarrow \mathrm{CH}_{4}(\mathrm{~g})+2 \mathrm{H}_{2} \mathrm{O}(1)
$$

This reaction is carried out by $M$. fornicicum and 1 s exothermic. The estimated exothermic heat of reaction ts 108,600 BTU per pound mol of methane produced. Energy consumed by the microorganisms for growth and malntenance are estimated to be 36,600 and 24,100 BTU per pound mol of 
methane produced, respectively. Based on the selected cell concentration ( $120 \mathrm{gm} / 11$ ter), packlng type (3" ceramic Raschig ring), and reactor dlameter, a serles of calculations were carrled out by the Unfversity of Arkansas at varlous bed helghts and percentage conversions to determine the limiting liquid circulation rates entering and leaving each bed of packing. A combined set of conditions with adequate liquid flows to achleve the required conversion and heat removal was determined and used for equipment design. This set of conditions indlcated that five beds are required at different percentage conversions in each bed. The percentage conversions are $24.5,30.5,43.0,58.0$ and 85.5 with bed depth of $5.75,5.75,5.75,5.0$ and 4.5 meters from top bed to bottom bed for an overall conversion of $98 \%$. By increasing the bottom two bed depth to 5.75 meters, the conversion can be increased to 63.0 and $93.0 \%$ respectively to achieve an overall co conversion of $99.2 \%$. The latter is used for this study.

\section{Medium Makeup Subsystem}

The process flow diagram for this subsystem is shown in Figure 5.4 . Chemical and mineral makeup to the system is prepared batchwise by mixing in the agltated Chemical Makeup Tank. The relatively concentrated makeup solution is added to the make-up process condensate by the metering pump through a mixing tee. The process condensate makeup to the system is stored in the medium storage tank along with recycled medium. The medium storage tank operates at $375 \mathrm{psig}$ has flve minutes of storage capacity. Normally, the medium flows under pressure through the heater where it is heated by $60 \mathrm{psig}$ steam to $280^{\circ} \mathrm{F}$ and held in the surge drum for three minutes to sterilize the medium. The sterilized medium is cooled to $100^{\circ} \mathrm{F}$ in the medium cooler and flows to the slurry Drum in the acetate production subsystem. A startup medium circulating pump has been supplied to provide medium circulation when varlous parts of the system are not yet at the required operating pressure.

\subsection{Heat and Materlal Balances}

The overall material balance for the blological conversion unit is summarized in Table 5.1, were the major process streams are keyed to the system block flow diagram (Flgure 5.1). Individual mass balances for the overall system, are given in Table 5.2. The overall water balance for the bloconversion unit is summarized in Table 5.3.

\subsection{Operat1ng Requirements}

Steam consumption and cooling water requirements for the bloconversion unit are summarlzed in Table 5.4. The normal electric power requirement for this unit is estimated at $7.6 \mathrm{MW}$ as shown in Table 5.5. 


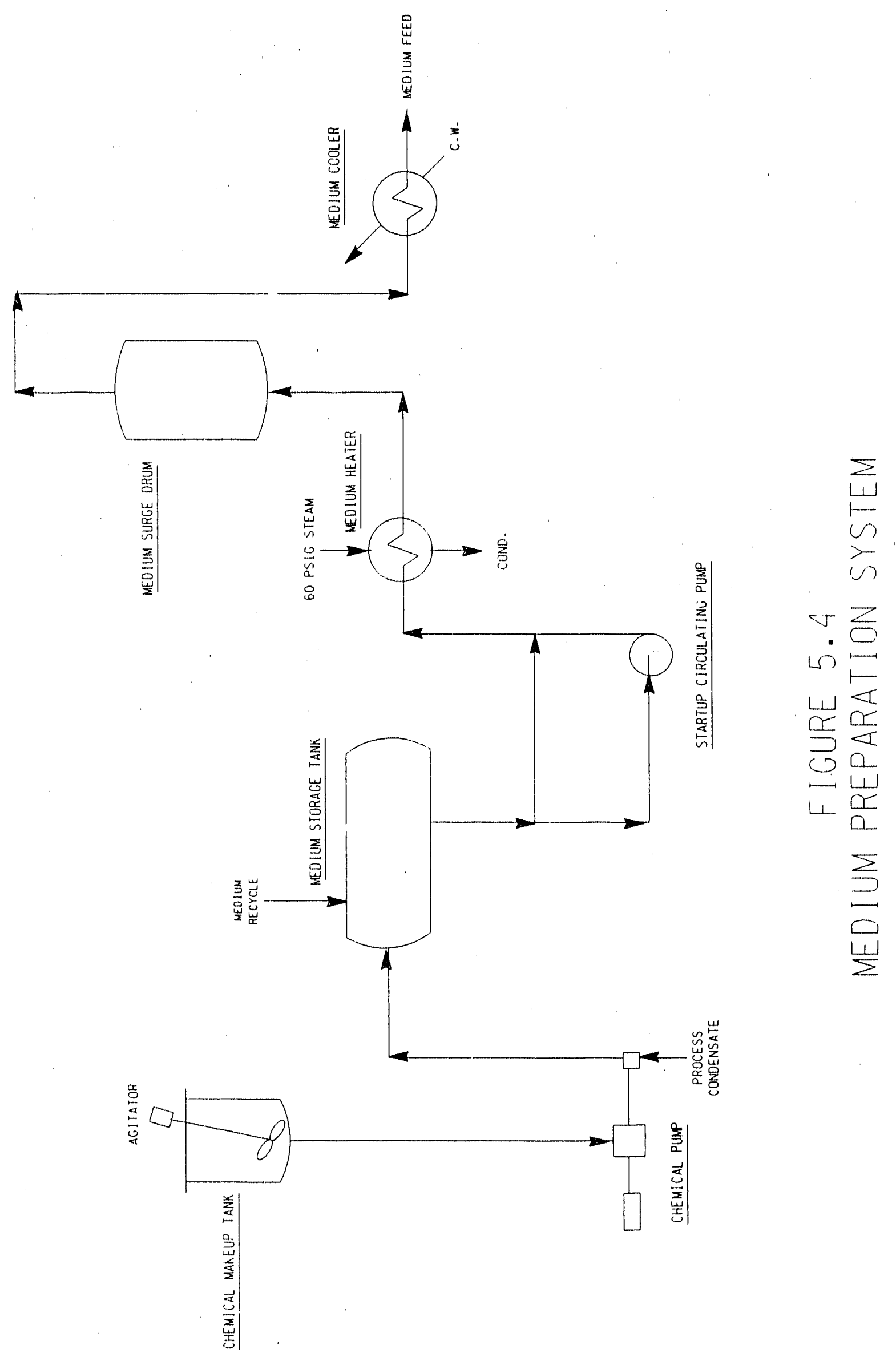

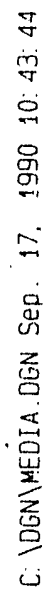




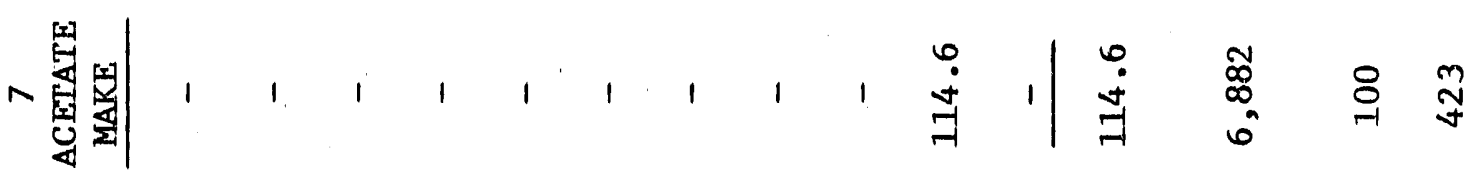

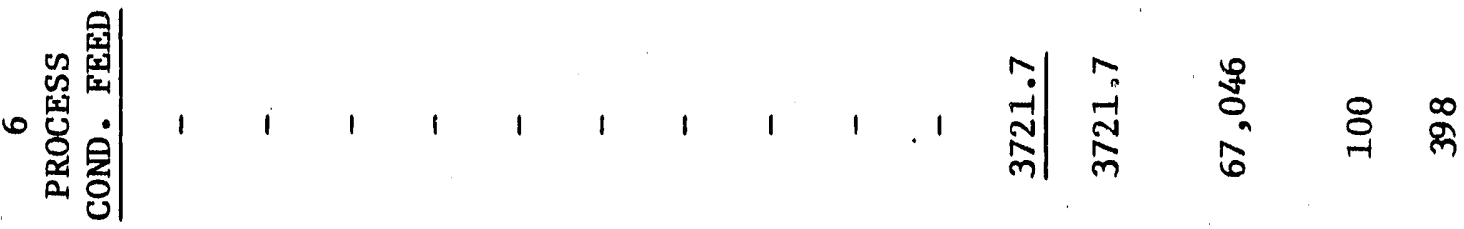

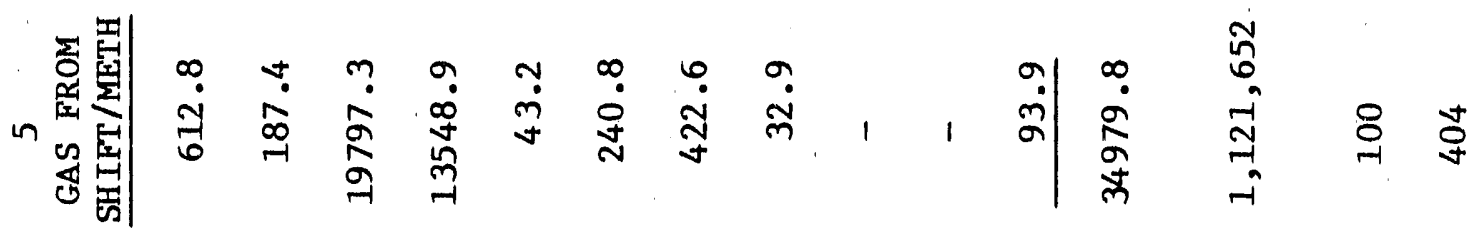

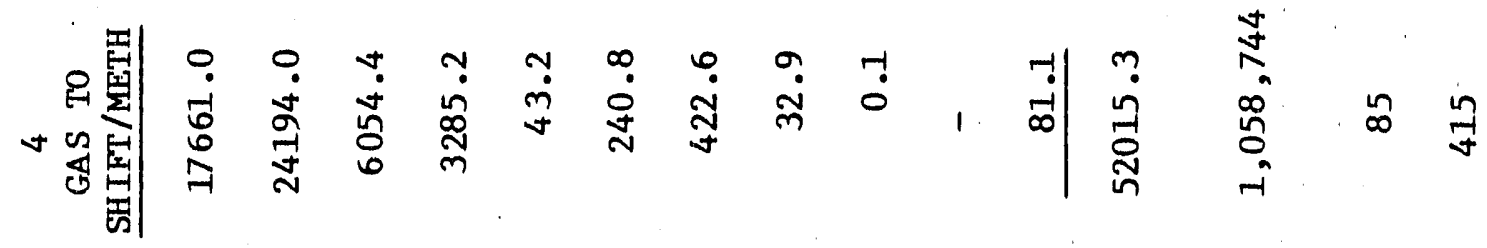

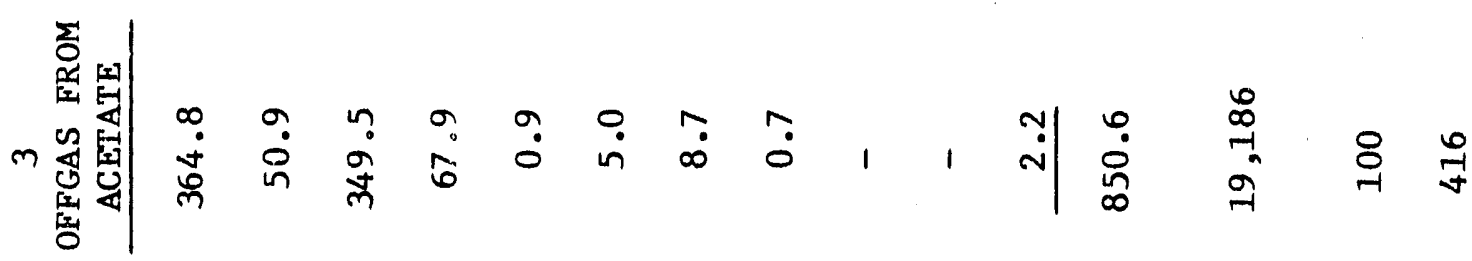

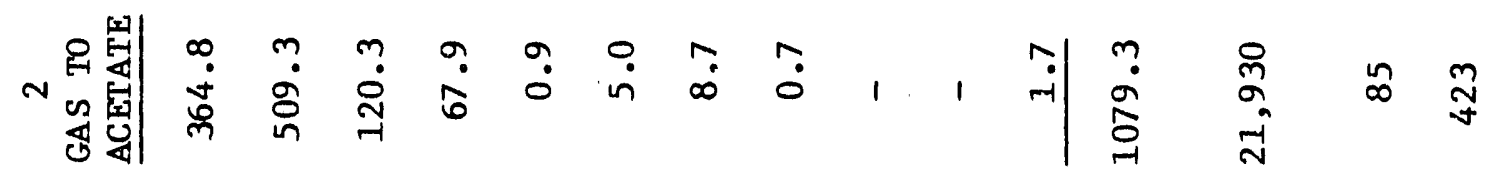

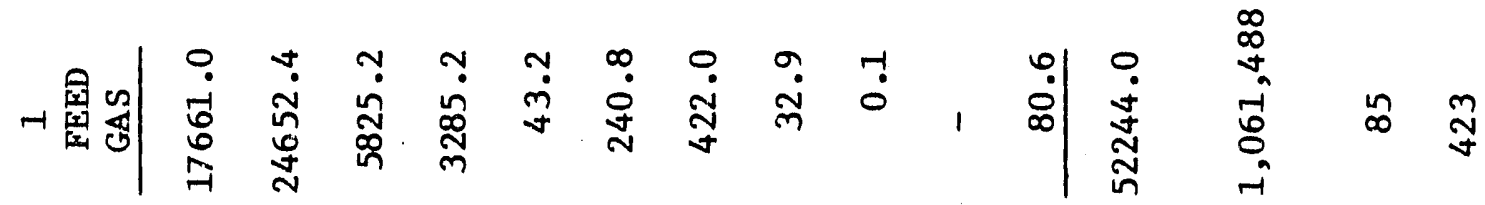

\&

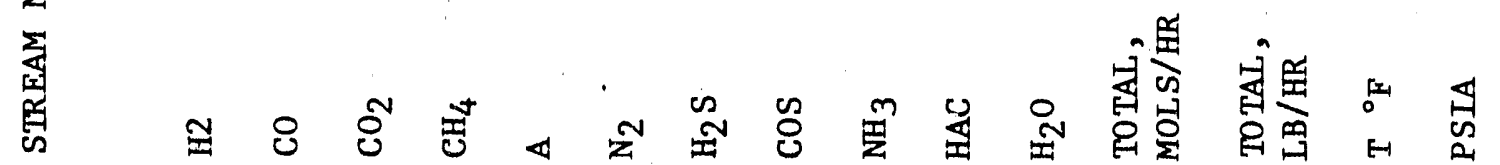




\section{MEDIUM PREPARATION SUBSYSTEM}

IBS/HR

Input

Recycled Medıum

146,510

Makeup Water

67,046

Tota1 Input

213,556

Output

Medium Flow

$\underline{213,556}$

Total Output

213,556

ACETATE PRODUCTION SUBSYSTEH

LBS/HR

Input

Medium Feed (Excluding Chemicals \& Minera1s)

213,556

Gas Feed

21,930

Total Input

235,486

output

Medium Flow

209,418

Gas out

19,186

Acetate Make

6,882

Total Output

235,486

$$
-35-
$$


SH IFT/METHANATION SUBSYSTEM

LBS/HR

Input

Raw Gas Feed

$1,039,558$

Offgas From Acetate Production

19,186

Medium Feed

209,418

Acetate Feed

6,882

Total Input

$1,275,044$

Output

Converted Gas

$1,121,652$

Medium Flow

146,510

Acetate Consumed

6,882

Total Output

$1,275,044$

OVERALL BALANCE

LBS/HR

Input

Gas Feed

$1,061,488$

Water Makeup

67,046

Total Input

$1,128,534$

output

Gas Out

$1,121,652$

Gas Consumed As Acetate

6,882

Total Output

$1,128,534$ 


\section{BIOCONVERSION SYSTEM WATER BALANCE}

LBS/HR

Input

Feed Gas

1,452

Process Condensate Make-up

67,040

matal Input

68,498

output

Product Gas

1,691

Consumed By Acetate Reaction

4,129

Net Consumed By Shift/Methanation Reaction

62,678

Total Output

68,498 


\section{BIOCONVERSION SYSTEM}

STEAM CONDENSATE AND COOLING WATER REQUIREMENTS

$$
\begin{gathered}
60 \text { PSIG Steam Consumption } \\
\text { To Medium Heater } \\
\text { Steam Condensate Produced } \\
\text { From Medium Heater } \\
\text { Cooling Water Requirements } \\
\text { Slurry Coolers (20) } \\
\text { Solution Coolers (10) } \\
\text { Medium Cooler (1) }
\end{gathered}
$$$$
42,11.5 \text { LBS/HR }
$$$$
42,115 \mathrm{LBS} / \mathrm{HR}
$$$$
\frac{G P M}{717} \frac{\mathrm{T}^{\circ} \mathrm{F}}{10}
$$$$
93,640 \quad 10
$$$$
\underline{(7,940) \quad 10}
$$$$
94,357 \quad 10.8
$$ 
TABLE 5.5

BIOCONVERSION SYSTEM

ELECTRIC POWER CONSUMPTION

\begin{tabular}{|c|c|}
\hline Acetate Production Subsystem & $\mathrm{KW}$ \\
\hline Agitators (2) & 828 \\
\hline Centrifuges (2) & 520 \\
\hline Slurry Pumps (2) & 114 \\
\hline Acetate Pumps (2) & 42 \\
\hline Subtotal & 1,504 \\
\hline \multicolumn{2}{|l|}{ Shift/Methanation Subsystem } \\
\hline Reactor Pumps (10) & 6,070 \\
\hline Reactor Illumination (10) & 30 \\
\hline Subtotal & 6,100 \\
\hline \multicolumn{2}{|l|}{ Medium Preparation } \\
\hline Agltator & 14 \\
\hline Chemical Pump (1) & 2 \\
\hline Subtotal & 16 \\
\hline Total & 7,620 \\
\hline
\end{tabular}




\subsection{Estimated Capital Costs}

The facility construction costs for each of the bioconversion subsystems was estlmated for a Westeru Pennsylvania site in mid-1985 dollars. The estimates were developed from major equipment speciflcations and factored to an installed cost basis. The following estimated costs exclude engineering and design costs, process development allowances, and profect contingency:

\begin{tabular}{lr} 
& \$MM \\
\cline { 2 - 2 } Acetate Production & 6.9 \\
Shift/Methanation & 70.2 \\
Medium Preparation & 0.8 \\
Total & 77.9
\end{tabular}




\subsection{INTEGRATED BIOCONVERSION-SNG PLANT}

The conceptual design for the coal-based SNG plant employing the bloconversion route for shift and methanation was developed as a grassroots facility, having a nominal capacity of 125 billion BTU/day of SNG from Pittsburgh No. 8 coal. The design was developed by integrating the bloconversion unit design, as described in section 5.0, into the process configuration for the conventional coal-based SNG plant.

\subsection{Plant Description}

A block flow diagram for the coal-based SNG plant employing the syngas bloconversion route is shown in Figure 6.1. The conceptual plant design incorporates the following processing unfts:

$$
\begin{aligned}
& 100 \text { - Coal Preparation } \\
& 1.50 \text { - Coal Drying and Grinding } \\
& 200 \text { - Gasification and Quench } \\
& 300 \text { - Gas Cooling } \\
& 400 \text { - Bloconversion Unit } \\
& 500 \text { - Acid Gas Removal } \\
& 600 \text { - SNG Compression } \\
& 700 \text { - } \mathrm{CO}_{2} \text { Compression } \\
& 800 \text { - Claus Sulfur Recovery } \\
& 850 \text { - Tall Gas Treating } \\
& 900 \text { - Sour Water Strtpping } \\
& 950 \text { - Ammonla Recovery }
\end{aligned}
$$

Description of these processing units is essentially the same as for the conventional coal-based SNG plant except for the following:

\section{0 - Gas Cooling}

The gas cooling section was re-designed to eliminate the catalytic shift and COS hydrolysis operations which were included in the conventional plant design. The revised design is 1llustrated by the process schematic in Figure 6.2. Accordingly, the quenched raw syngas from the gasification section is cooled from $301^{\circ} \mathrm{F}$ to $85^{\circ} \mathrm{F}$ by a serfes of indirect heat exchangers which preheat boller feed water and steam condensate, followed by heat rejection to air fan coolers and cooling water.

The cooled syngas stream is sent to the Bloconversion Unit while the aqueous condensate is processed in the Sour Water Stripping unit. 


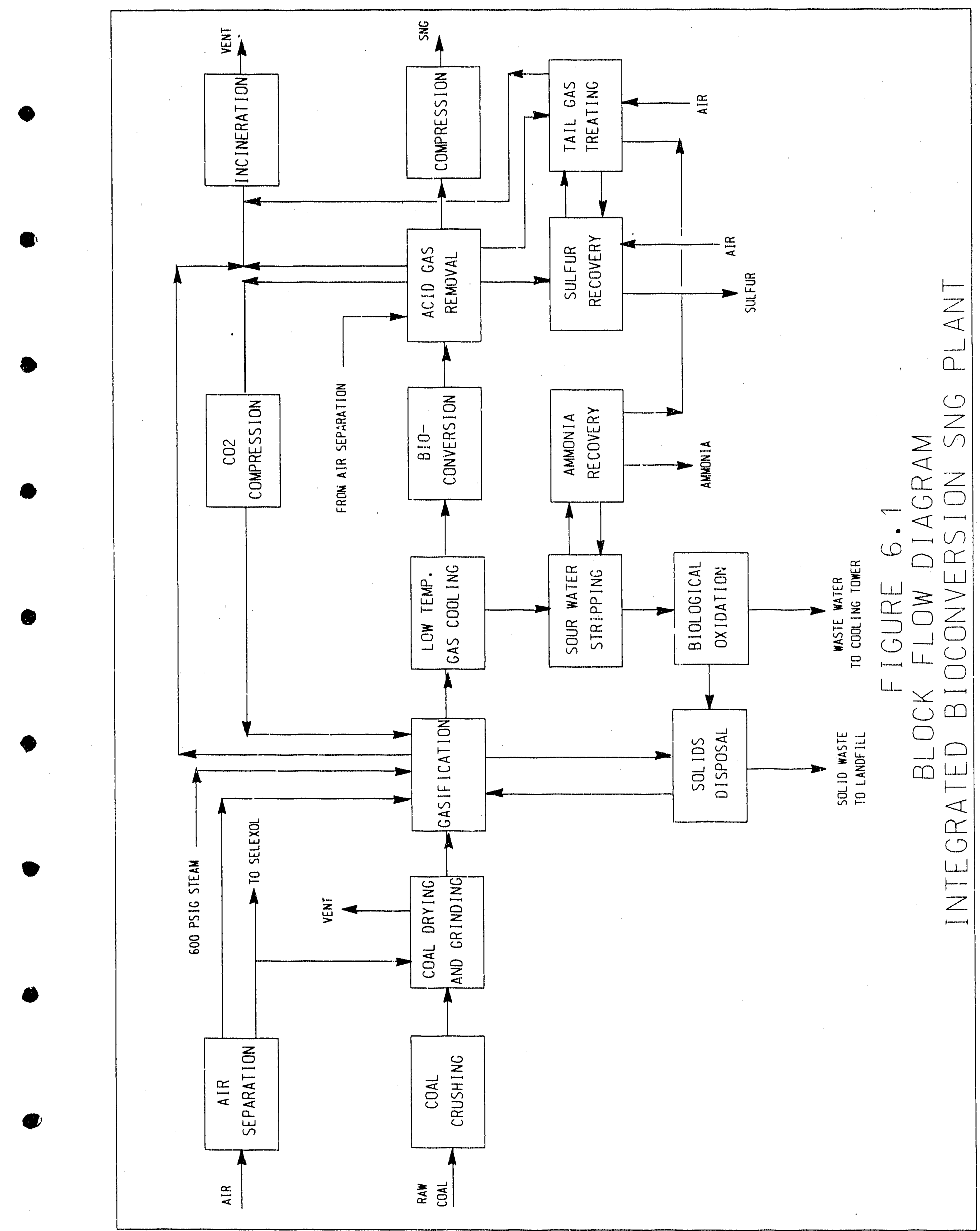

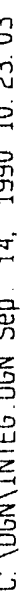




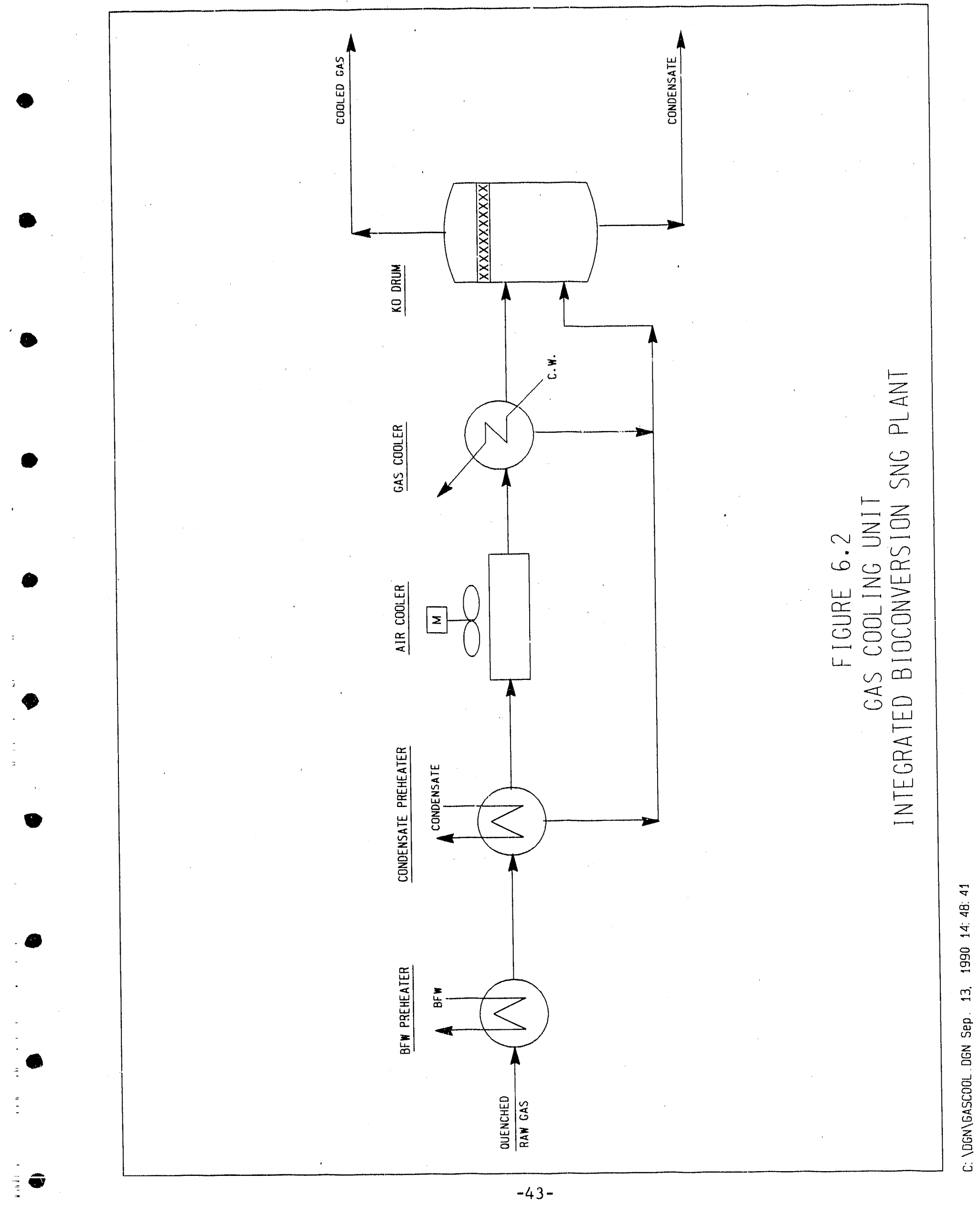


As described in section 5.0, the bloconversion unit design consists of the following subsystems:

\begin{tabular}{lr} 
Subsystem & No. Trains \\
\cline { 2 - 2 } Acetate Production & 2 \\
Shlft/Methanation & 10 \\
Medium Preparation & 1
\end{tabular}

This unit replaces the catalytic shift and methanation processing steps In the conventional coal-based SNG plant design. Raw syngas from the Gas cooling unit is processed in a two-stage blological conversion system where, via the action of a mixed mircoorganism culture, essentially all of the $\mathrm{CO}$ and $\mathrm{H}_{2}$ are converted to methane. Since the biological reactions occur at $100^{\circ} \mathrm{F}$, there is no recovery of the exothermic heat of reaction, as is possible in the catalytic route. Consequently, the net heat of reaction is rejected to coriling water. Product gas from bioconversion is sent to the Acid Gas Removal system for removal of $\mathrm{CO}_{2}$ and sulfur compounds.

500 - Acld Gas Removal

Feed gas to the Acld Gas Removal system is the methanated gas from the bloconversion system. Consequently, the molar gas flow to this system is greatly reduced compared to the catalytic conversion case where a shifted gas is fed to the Acid Gas Removal system. Norton Company provided the basis for the bioconversion case design.

$600-$ SNG Compression

After being treated in the Acld Gas Removal system, the product SNG stream is essentially bone-dry. Therefore, there is no need for a glycol dehydration unit to dry the SNG product as in the conventional processing route. In this unit, the product SNG stream is compressed from 370 psig and delivered at $1000 \mathrm{psig}$ and $95^{\circ} \mathrm{F}$.

\section{Support Facilities}

As with the conventional coal-based plant design, the integrated bloconversion SNG plant is provided with all the necessary offsite units and support systems to supply ut1lities, meet environmental regulations, and malntain plant operation. These systems include the following:

$$
\begin{array}{ll}
\text { 1000- } & \text { Alr Separation } \\
1100- & \text { Blological Oxidation } \\
2000- & \text { Stear Generation }
\end{array}
$$




$\begin{array}{ll}2100- & \text { Power Generation } \\ 2200- & \text { Solids Disposal } \\ 2300- & \text { Plant Water System } \\ 2400- & \text { Waste Water Evaporation } \\ 2500- & \text { Coal Recelving \& Storage } \\ 2600- & \text { Cooling Water System } \\ 2700- & \text { Vent Gas Incinerator } \\ 2800- & \text { General Facllities }\end{array}$

These systems serve the same functions as in the conventional plant design. A major difference, however, is in the steam generation section where a coal-fired steam generator was added to satisfy the plant steam requirements.

\subsection{Mass and Energy Balances}

The overal1 mass and energy balances for the integrated SNG plant based on the bioconversion route are summarlzed in Table 6.1. The cold gas efficiency for this plant is about $60 \%$ compared to $68 \%$ for the conventional coal-based SNG plant. The lower efflclency is directly attributable to the additlonal coal required for plant steam generation in the bloconversion route.

\subsection{Operating Summary}

The Integrated SNG plant is designed as a grassroots facility such that only coal, raw water, and consumable catalysts and chemicals are supplied from external sources. The plant steam, electric power, and cooling water requirements are provided from in-plant sources. The following summarizes the overall plant performance:

$\begin{array}{cr}\text { Coal Feed, TPD (as recvd) } & \\ \text { Gasification } & 7,780 \\ \text { Steam Generation } & \frac{875}{8,655} \\ & \\ \text { Limestone, TPD } & 207 \\ \text { Raw Water, GPM } & 5,175 \\ \text { SNG Product, MMSCFD } & 129.5 \\ \mathrm{HHV}, \mathrm{BTU} / \mathrm{SCF} & 952 \\ \text { Volume \% } & 92.33 \\ \mathrm{CH} & 4.21 \\ \mathrm{H}_{2} & 1.28 \\ \mathrm{CO} & 0.22 \\ \mathrm{CO}_{2} & 1.95 \\ \mathrm{~N}_{2}{ }^{+} \mathrm{A} & 0.01 \\ \mathrm{H}_{2}{ }^{\circ} & 100.00\end{array}$


TABLE 6.1

OVERALL MASS AND ENERGY BALANCES

\section{BIOCONVERSION SNG PLANT}

INPUT

As Recelved Coal

Oxygen to Gasifiers

Combustion Air

N1 trogen

Raw Water

Iimestone

Tota1

OUTPUT

SNG Product

Sulfur

Ammonia

Stack Gases

Water Losses

Cooling Water Loss

Steam System Loss

Solids to Disposal

Bloconversion Loss

Alr Cooling \& Misc.

Tota1

$\mathrm{LB} / \mathrm{HR}$

721,119

381,818

$1,037,689$

483,032

$2,587,475$

11,800

$5,222,933$

226,264

14,884

1,885

$2,502,352$

26,634

$2,305,628$

1,500

143,786

-

$-$

$5,220,022$
MMBTU/HR

8564.1

20.3

10.2

7.6

$-$

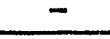

8602.2

5143.6

58.1

17.3

181.0

$-$

1887.9

1.6

272.0

623.1

417.6

8602.2 


$$
\begin{array}{lr}
\text { By-Products: } \begin{array}{c}
\text { Sulfur, TPD } \\
\text { Ammonia, TPD }
\end{array} & 265 \\
\text { Solids to Disposal, TPD } & 1,725 \\
\text { Catalyst \& Chemlcals, \$/Day } & 2,149
\end{array}
$$

The SNG product is dellvered at $95^{\circ} \mathrm{F}$ and $1000 \mathrm{psig}$ and meets all the established specifications except for CO content. Despite an overall CO conversion of $99.2 \%$ in the bloconversion unit, the residual co content in the SNG product is about $1.3 \%$ compared to the maximum speciflcation level of $0.1 \%$. In order to reduce the $C 0$ level to less than $0.1 \%$, a catalytic trim methanation unit is required. The economic impact of meeting the $\mathrm{CO}$ specification of $0.1 \%$ is addressed in Section 7.5 of this report.

The normal plant electrlc power requirement is approximately $30 \mathrm{MW}$, as summarized in Table 6.2 . This requirement is satisfled by in-plant power generation via steam turbine generators. Electric power usage is minimized by driving all large compressors and pumps with steam turbines. The normal power usage is about $70 \%$ higher than that for the conventional SNG plant. Power usage in the bloconversion unit of $7.6 \mathrm{MW}$ and Increased cooling water usage, which translates to an additional 5.4 MW, account for the difference.

As in the conventional plant design, water cooled exchangers are used for all steam turbine surface condensers and for most cooling services below $140^{\circ} \mathrm{F}$. The overall plant cooling water circulation, as summarlzed in Table 6.3 , is $210,940 \mathrm{gpm}$ which corresponds to a heat removal duty of $1,888 \mathrm{MMBTU} / \mathrm{HR}$.

The overall plant steam balance is satisfied by operating a coal-fired circulating fluid-bed boller to generate 1500 psig steam. This auxillary boller was needed since there is no waste heat recovery in the blological shift/methanation section. In addition to firing 875 TPD of coal for steam generation, the plant uses a small quantity of product gas, about 3.0 MMSCFD, to fire steam superheaters and to supply reducing gas for the SCOT Tall Gas Treating unit.

\subsection{Est1mated Capita1 Costs}

Cost estimates for the coal-based SNG plant employing the bloconversion route were developed on a mid-1985 basls for a Western Pennsylvanla site. A project contingency was included to account for uncertainties in technical definition and estimating techniques. However, since the plant design is assumed to be based on mature technology, the cost estimates do not Include any process development allowance. 
TABLE 6.2

\section{BIOCONVERSION SNG PLANT}

ELECIRIC POWER REQUIREMENT

\begin{tabular}{c} 
AREA \\
\hline 100 \\
150 \\
200 \\
300 \\
400 \\
500 \\
800 \\
850 \\
900 \\
950 \\
1000 \\
1100 \\
2000 \\
2200 \\
2300 \\
2400 \\
2500 \\
2600 \\
2700 \\
2800
\end{tabular}

DESCRIPTION

$\mathrm{KW}$

Coal Preparation

353

Coal Drying \& Grinding

2,715

Gasification \& Quench

3,047

Gas Cooling

300

Bloconverston Unit

Acid Gas Removal

Claus Sulfur Recovery

Tall Gas Treating

Sour Gas Stripplng

Ammonia Recovery

Alr Separation

Blological Oxidation

, 620

370

280

690

163

283

(854)

132

735

Steam Generation

34

Solitds Disposal

520

Waste Water Evaporation

31

Coal Recelving \& Storage

360

Cooling Water System

Vent Gas Incinerator

11,838

General Facilities

85

1,300

Total

30,002 
TABLE 6.3

BIOCONVERSION SNG PLANT

PLANT COOLING WATER USAGE

\begin{tabular}{llrc} 
AREA & \multicolumn{1}{c}{ DESCRIPTION } & GPM & $\Delta \mathrm{T}^{\circ} \mathrm{F}$ \\
\cline { 2 - 4 } 200 & Gasification \& Quench & 3,013 & 30 \\
300 & Gas Cooling & 2,410 & 30 \\
400 & Bloconversion Unit & 94,360 & 11 \\
500 & Acld Gas Removal & 16,420 & 30 \\
600 & SNG Compression & 1,580 & 30 \\
700 & CO2 Compression & 420 & 30 \\
850 & Tail Gas Ireating & 2,807 & 30 \\
950 & Ammonia Recovery & 347 & 30 \\
1000 & Air Separation & 14,313 & 30 \\
2100 & Power Generation & $\underline{75,270}$ & 20 \\
& Total & 210,940 & 17.9
\end{tabular}


The facilities construction costs for the processing units and support systems are summarized in Tables 6.4 and 6.5 , respectively. Costs for Section 300 - Gas Coollng, Section 400 - Bloconversion Unit, and Section 2000 - Steam Generation were developed by Foster wheeler from major equipment specifications. Costs for the other plant sections were prorated on capacity from the corresponding costs for the conventional coal-based SNG plant, as presented in section 4.0 of this report. The estimated total plant investment and total capital investment are detalled in Table 6.6.

Capital costs for the bloconversion route compare to the conventional catalytic processing route as follows:

\begin{tabular}{|c|c|c|}
\hline & $\begin{array}{c}\text { Conventional } \\
\text { Route } \\
\end{array}$ & $\begin{array}{c}\text { Bioconversion } \\
\text { Route }\end{array}$ \\
\hline Processing Facilities Cost, \$MM & 353 & 365 \\
\hline Support Fac1lities Cost, \$MM & 263 & 287. \\
\hline Total Plant Investment, \$MM & 890 & 922 \\
\hline
\end{tabular}

The facilities construction costs for the bloconversion plant are about $3 \%$ higher while the total plant investment cost is about $4 \%$ higher than the conventional processing route. 
TABLE 6.4

\section{BIOCONVERSION SNG PLANT}

\section{ESTIMATED PROCESSING FACILITIES COST}

Basis: Mid - 1985

\begin{tabular}{|c|c|c|c|}
\hline & Plant Section & No. Trains & $\begin{array}{c}\text { Base FCI } \\
\$ M M \\
\end{array}$ \\
\hline 100 & Coal Preparation & $2+1$ & 26.4 \\
\hline 200 & Gasification \& Quench & $6+1$ & 185.0 \\
\hline 300 & Gas Cooling & 2 & 6.8 \\
\hline 400 & Bloconversion Unit & & 77.9 \\
\hline 500 & Acld Gas Removal & 2 & 40.0 \\
\hline 600 & Sirg Compression & 2 & 6.0 \\
\hline 700 & $\mathrm{CO}_{2}$ Compression & 2 & 4.0 \\
\hline 800 & Claus Sulfur Recovery & $1+1$ & 7.0 \\
\hline 850 & Tall Gas Treating & 1 & 5.0 \\
\hline 900 & Sour Water Treating & 2 & 3.1 \\
\hline 950 & Ammonia Recovery & 2 & 3.3 \\
\hline & Total FCI* & & 364.5 \\
\hline
\end{tabular}


TABLE 6.5

\section{BIOCONVERSION SNG PLANT}

ESTIMATED SUPPORT FACILITIES COST

Basis: Mid - 1985

\begin{tabular}{|c|c|c|c|}
\hline & Plant Section & No. Trains & $\begin{array}{c}\text { Base FCI } \\
\$ M M\end{array}$ \\
\hline 1000 & Air Separation & 2 & 86.0 \\
\hline 1100 & Blological oxidation & 1 & 4.1 \\
\hline 2000 & Steam Generation & 2 & 42.0 \\
\hline 2100 & Power Generation & $2+1$ & 11.6 \\
\hline 2200 & Sollds DIsposal. & 1 & 9.2 \\
\hline 2300 & Plant Water System & & 2.9 \\
\hline 2400 & Waste Water Evaporation & 1 & 5.8 \\
\hline 2500 & Coal Recelving \& Storage & & 16.2 \\
\hline 2600 & Cooling Water Systems & 1 & 7.6 \\
\hline 2700 & Vent Gas Incinerator & 1 & 9.3 \\
\hline 2800 & General Fac1lities & & 92.0 \\
\hline & Total FCI* & & 286.7 \\
\hline
\end{tabular}

* Facilities Construction Investment 


\section{TABLE 6.6}

\section{BIOCONVERSION SNG PLANT}

\section{SUMMARY OF CAPITAL COSTS}

Bas1s: Mid - 1985

\begin{tabular}{|c|c|}
\hline & $\$ M M$ \\
\hline $\begin{array}{l}\text { Processing Facilities Cost } \\
\text { Support Facilities Cost } \\
\text { Project Contingency a 15\% }\end{array}$ & $\begin{array}{r}364.5 \\
286.7 \\
97.7 \\
\end{array}$ \\
\hline Direct FCI* & 748.9 \\
\hline Engineering \& Design Cost \& $13.5 \%$ & 101.1 \\
\hline Total FCI* & 850.0 \\
\hline $\begin{array}{l}\text { Inftla L Catalyst Inventory } \\
\text { Paid-up Royalty } \\
\text { Start-up Cost }\end{array}$ & $\begin{array}{r}1.3 \\
6.0 \\
65.0 \\
\end{array}$ \\
\hline Total Plant Investment & 922.3 \\
\hline \multicolumn{2}{|l|}{ Working Capita1: } \\
\hline $\begin{array}{l}\text { Coal Inventory } \\
\text { Materlals \& Supplies } \\
\text { Spare Part.s } \\
\text { Land }\end{array}$ & $\begin{array}{r}13.3 \\
7.2 \\
7.1 \\
1.0 \\
28.6\end{array}$ \\
\hline
\end{tabular}




\subsection{ECONOMIC EVALUATION}

\subsection{Economic Guidelines}

The following economic guldelines as proposed by GRI ( 1 ) were used to determine the annual operating and malntenance costs for the integrated coal-based SNG plants.

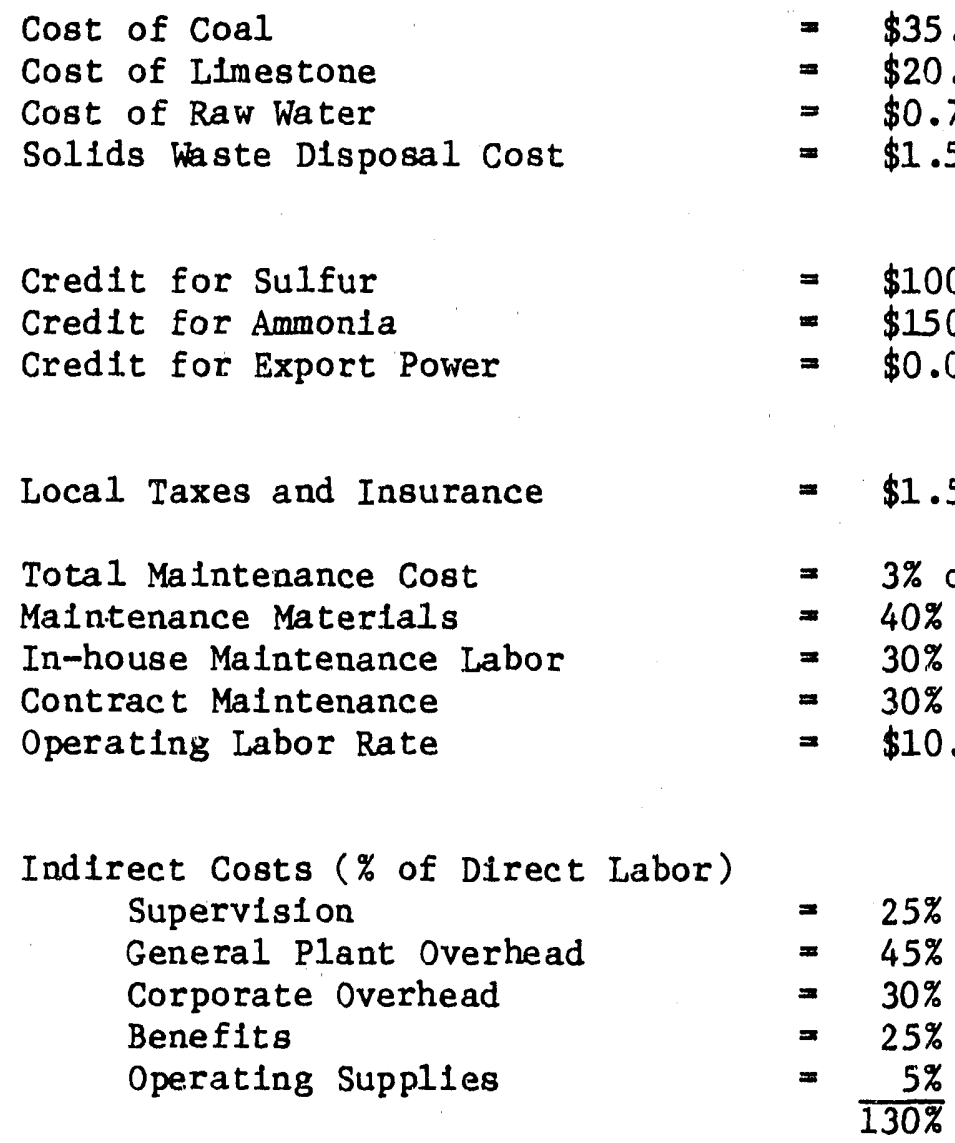

\section{Notes:}

1. TFCI $=$ Total Facllities Construction Investment.

2. DFCI = Direct Facilities Construction Investment.

3. PC = Project Contingency.

4. Direct Labor Cost is the sum of Operating Labor Cost plus In-House Malntenance Labor Cost.

5. TMC = Total MaIntenance Cost. 
The economic parameters used to calculate the levelized constant dollar cost-of-gas are given below. These parameters were based on the GRI guldelines ( 1 ), but modifled to eliminate lnvestment tax credits and accelerated cost recovery schedule.

$\begin{array}{ll}\text { Book LIfe, Years } & 30 \\ \text { Tax Life, Years } & 30 \\ \text { Inflation Rate } & 0.06 \\ \text { Fue1 Inflation } & 0.072 \\ \text { Base Year } & 1985 \\ \text { Construction Per1od, Years } & 4 \\ \text { Comblned State and FederaI Tax Rate } & 0.5 \\ \text { Service Factor } & 0.9 \\ \text { Debt/Common Equity } & 0.5 / 0.5 \\ \text { Average Cost of Capital } & 0.1185 \\ \text { Rate of Return on AFUDC } & 0.1185\end{array}$

\subsection{Annual Operating and Maintenance Costs}

Annual operating and malntenance costs for the Integrated coal-based SNG plant designs, based on the conventional catalytic conversion of syngas and on the bloconversion of syngas, are shown in Table 7.1. These annual costs are based on a stream factor of $100 \%$.

\subsection{Levelized SNG Cost}

Levelized constant-dollar cost of SNG produced by means of conventional catalytic conversion and bloconversion of syngas are shown in Table 7.2. The higher capital cost and higher varlable operating and maintenance cost for the bioconversion route results in $8 \%$ higher cost of SNG.

\subsection{Effect of Purchased Acet1c Actd}

The use of $R$. rubrum for the bloconversion of syngas to methane requires a carbon source other than $\mathrm{CO}$ and $\mathrm{CO}_{2}$. For this reason, a small amount of acetate is added to the reaction medium. The required acetate can be conventently produced from $\mathrm{CO}$ and water uslng the microorganlsm $P$. productus.

For the integrated SNG plant employing the bioconversion route, 6,880 pounds per hour of acetic acld is consumed for growth of $R$. rubrum. The estimated facility construction investment required to produce this amount of acetic acid via in-plant bloconversion is $\$ 9.0$ militon. This investment requirement and the gas used for acetate production can be eliminated if purchased acetic acid is used. The cost of acetic actd dellvered in tank trucks, in mid-1985 dollars, is about 25k per pound. 
TABLE 7.1

OPERATING AND MAINTENANCE COSTS

Nominal 125 Billion Btu/Day Coal-to-SNG Facility

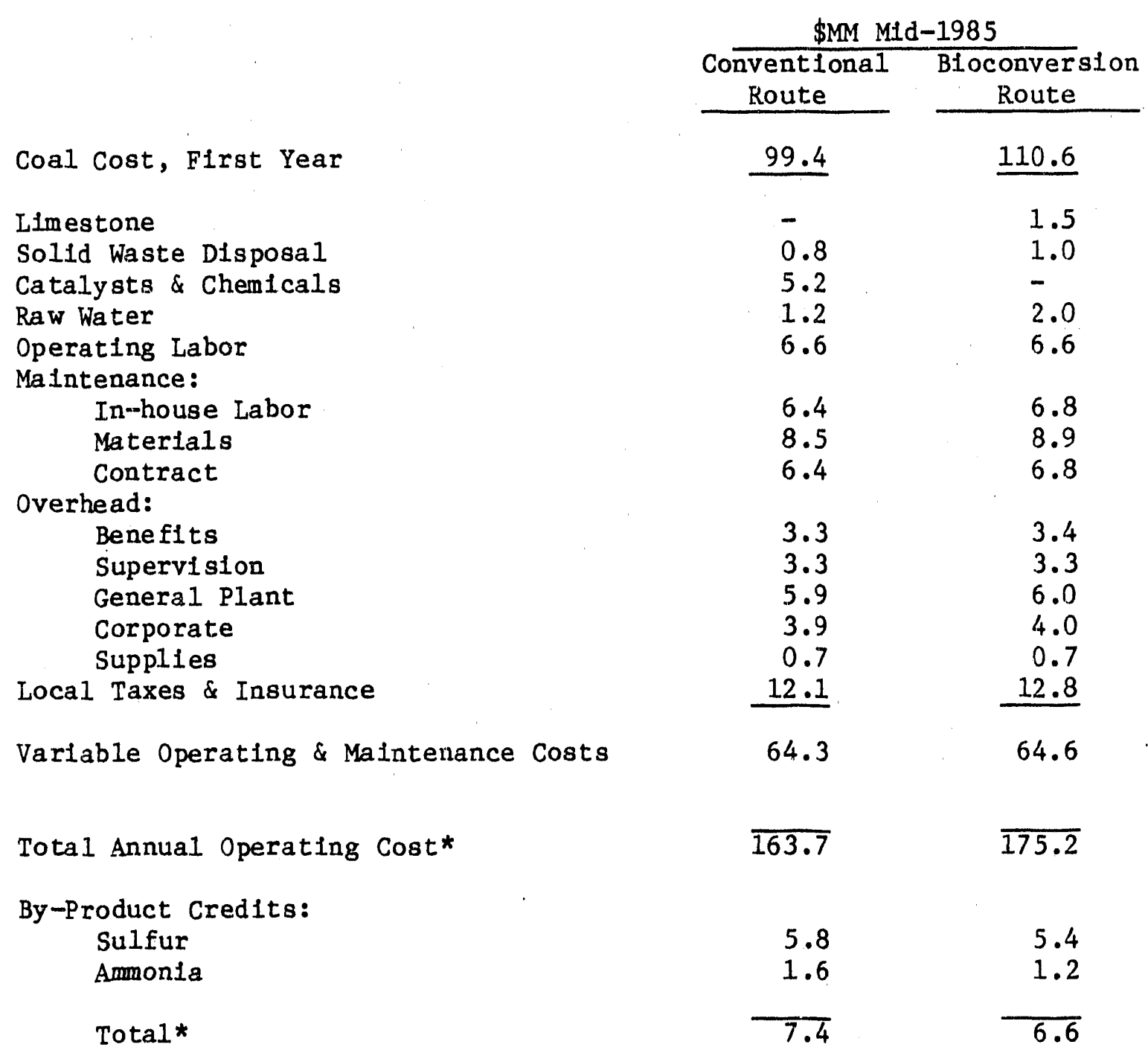

* At $100 \%$ stream factor. 
TABLE 7.2

LEVELIZED CONSTANT-DOILAR COST-OF-GAS

Nominal 125 Bil11on Btu/Day Coal-to-SNG Fac1lity

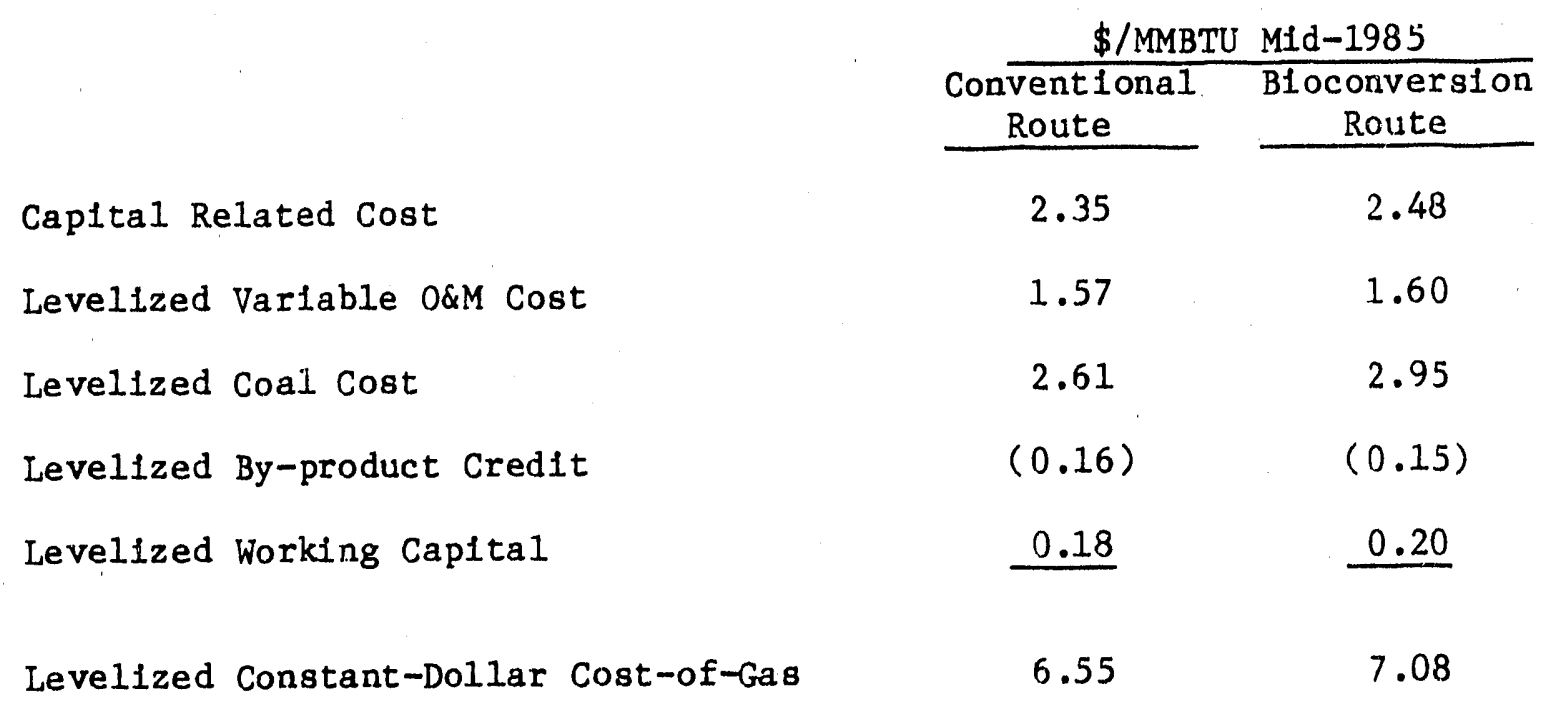


Hence, the annual cost of purchasing the required amount of acetic acid w11l amount to $\$ 15.0$ million. The purchased acetic acld cost can be reduced by the credit for additional fuel gas production, which is estimated to have a value of $\$ 2.7$ m1111on. Even w1th this fuel gas credit, there is st111. good reason to produce the required acetic acid Internally instead of purchasing acetic acid. Only when the delivered cost of acetic acid is less than $20 \mathrm{k}$ per pound will the annual purchase cost equal the investment cost less product gas credit.

\subsection{Effect of SNG Product Specification}

The SNG produced in the integrated bloconversion SNG plant, as described In section 6.0 of this report, is fully interchangeable with the referenced natural gas given in the GRI guidelines (1). The calculated interchangeability index values for this SNG are given below along with the limiting AGA Indices:

\begin{tabular}{|c|c|c|}
\hline Index & $\begin{array}{l}\text { Calculated } \\
\text { Value }\end{array}$ & $\begin{array}{l}\text { Limiting } \\
\text { Value }\end{array}$ \\
\hline $\begin{array}{l}\text { L1fting } \\
\text { Flashback } \\
\text { Yellow Tip }\end{array}$ & $\begin{array}{l}1.015 \\
1.053 \\
1.138\end{array}$ & $\begin{array}{l}1.06 \text { max. } \\
1.20 \text { max. } \\
0.80 \mathrm{mln} .\end{array}$ \\
\hline
\end{tabular}

The product SNG also meets all the GRI guideline speciflcations with the exception of $C O$ content where the specification is 0.1 volume percent while the product gas contains nearly 1.3 volume percent. Co content in the product SNG can be reduced to $0.1 \%$ by the addition of a single stage catalytic trim methanation unft downstream of the acid gas removal unit. The trim methanation unit must be followed by gas drying to reduce the molsture content to the speciffcation level of 7 pounds per million standard cubic feet. The dried SNG product gas is then compressed to $1000 \mathrm{psig}$. The process flow diagram for such a trim methanation unt as well as how this unit fits into the overall integrated bioconversion SNG plant is shown in Figure 7.1. The increase in investment to reduce the CO content of the product SNG to the specification level is estimated to be $\$ 10.0$ militon. In addition to the increase in plant cost, the operating costs will also increase to cool the methanated gas, to supply utilities for the gas drying unft, and to compensate for the lower suction pressure at the product SNG compressor. 


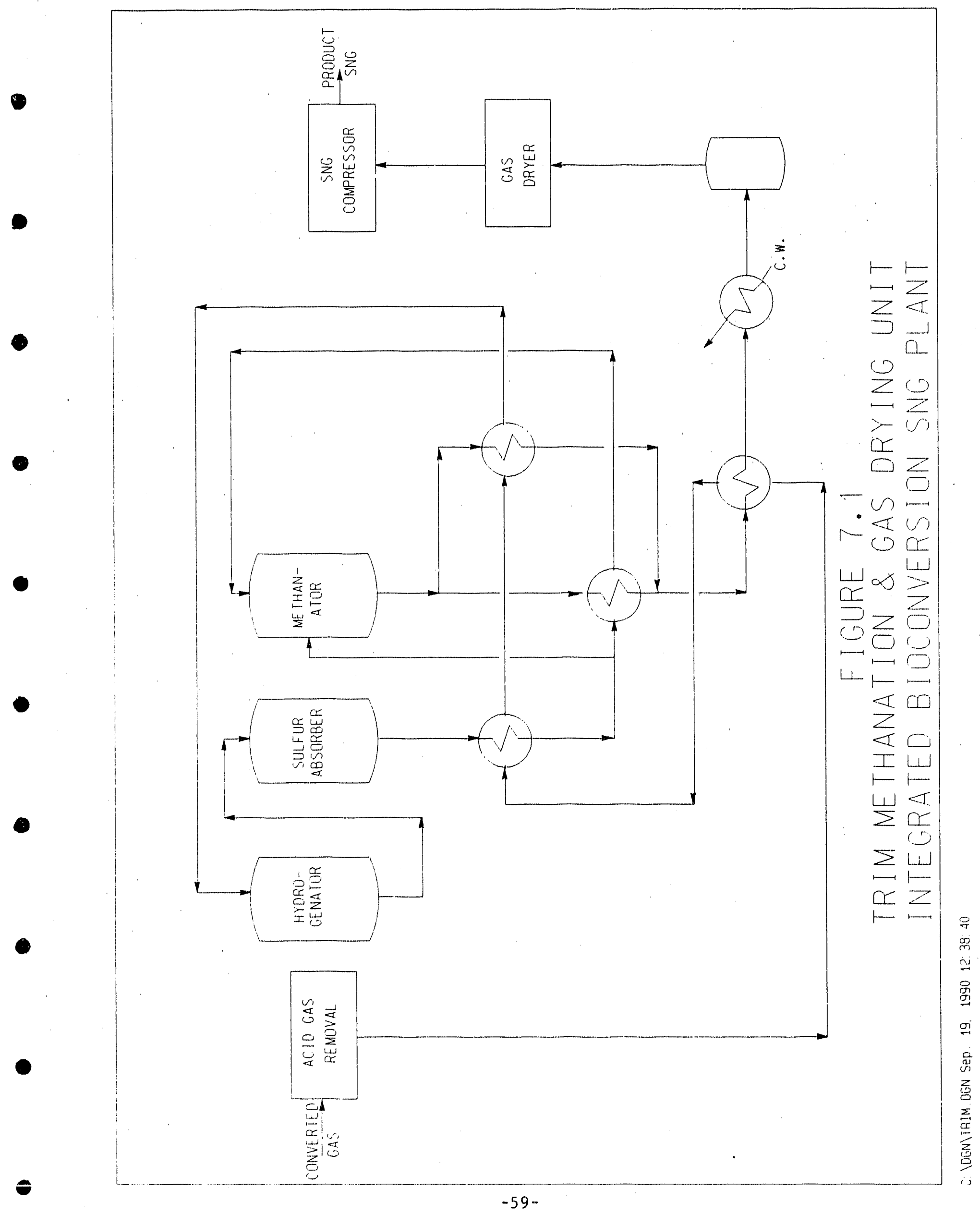




\subsection{CONCLUSIONS AND RECOMMENDATIONS}

\subsection{Bloconversion for SNG Production}

Bloconversion of coal-derlved syngas for SNG production, based on the conceptual design developed in this study, Indicates that the capital requirement as well as the variable operating and malntenance costs are higher than that for the conventional coal-based SNG plant. The onsite capltal requirement based on bioconversion is higher than that of the conventional catalytic route. This difference is essentlally due to the bloconversion unit which is nearly $\$ 41$ million more than the catalytic methanation unit. The greatest impact of the bloconversion unit cost is in the cost of the shift/methanation subsystem which has been estimated to cost $\$ 7.0$ million per train, for ten parallel tralns. In this subsystem, feed gas to each train is processed through five stages of packed bed reactor. Reduction in the number of stages can reduce the cost per train but at a penalty of lower Co conversion. For example, if $90 \%$ CO conversion is acceptable versus $99.2 \%$ conversion for the present design, the cost per train could be reduced to approximately $\$ 5.75$ million. This indicates that even at $90 \%$ CO conversion the shift/methanation subsystem, and hence the bioconversion plant, will still cost more than the conventional catalytic conversion plant.

Bloconversion is carried out at near ambient temperatures ( $90-100^{\circ} \mathrm{F}$ ) and, therefore, exothermic heat of reaction must also be removed at these low temperatures. Heat at this temperature level cannot be conveniently recovered as useful energy. Tn this conceptual design, reaction heat is not recovered and is rejected to cooling water. However, conventlonal catalytic conversion is carried out at temperatures ranging from 450 to $900^{\circ} \mathrm{F}$ and, under these conditions, heat recovery by steam generation is possible. For this reason the bioconversion plant requires a normally operating steam generator. For this study a limestone infected circulating fluldized-bed boller with bag house and stack for flue gas handling has been included. This results in higher offsite facilities investment cost for the bloconversion plant.

The present blological conversion system design is focused on the shift and methanation reactions only. Potentially, the economics for the bloconversion route to SNG could be improved with simultaneous blological conversion of sulfur compounds in the synthesis gas. Costs for the acid gas removal unit would be dramatically reduced and the need for sulfur recovery and tall gas treating unlts could possibly be eliminated. Microorganisms do exist that can consume and remove sulfur compounds, such as $\mathrm{H}_{2} \mathrm{~S}$ and COS. Addition research is needed, however, to determine the optimum organism or mixed culture that can be used for sulfur removal. 
In terms of operating cost, the $108 s$ of reaction heat in the bloconversion plant results in a heavy penalty in coal feed requirement. Additional coal, needed for steam generation, amounts to $\$ 10.2$ million. per year over the catalytic conversion plant. This is the principal reason for the higher annual operating cost for the bloconversion plant.

The blological shift/methanation system as is presently designed was based on a spectflc straln of $R$. rubrum, cell concentrations of 120 $\mathrm{gm} / 11$ ter, and a medium temperature rise of $10^{\circ} \mathrm{F}$. These are belleved to be reasonable values. It is anticlpated that if a more virlle strain of $R$. rubrum can be developed and proven to be effectlve, higher cell concentrations such as $300 \mathrm{gm} / 1$ iter and higher medium temperature rise such as 15 to $20^{\circ} \mathrm{F}$ can be used and the number of parallel reactor vessels can be greatly reduced. The University of Arkansas Indicates that it may be possible to reduce the number of parallel reactors from ten to two with these changes. These changes could reduce the process faclilty construction investment to favor the bioconversion route.

The shift methanation reactor can also be designed with cooling colls in each packed section so that reaction heat removal will not entirely be dependent on medium circulation. This could reduce the number of parallel reactors required but w111 increase the cost of the reactor.

Although it is concluded that bioconversion of coal-derived syngas to SNG is not yet competitive based on this conceptual design study, several areas have been 1dentifled for further study to narrow the gap. The areas recommended for future $R \& D$ effort include:

- Simultaneous sulfur removal.

- More virile strain of mlcroorganisms for shlft conversion.

- Improved reactor design to allow for more efficlent heat removal.

While bloconversion of syngas is not likely to be competitive with catalytic conversion to produce SNG from coal, there could be a niche for bloconversion in the production of higher valued products, such as acetic acid. Catalytic conversion of syngas to acet1c actd requires the production of methanol followed by methanol carboxylation. This is a complicated two step process compared to bloconversion for acetic acid production as is practiced in this study. 


\subsection{Bloconversion for Hydrogen Production}

The selected bloconversion process can also be used to produce hydrogen. The only change required is to eliminate the $M$. formicicum culture in the mixed culture reactors for shift/methanation. Since the absorption of CO into the medium solution is the controlilng resistance in the shift/ methanation reaction system, it is expected that the cost of the shift reaction system for hydrogen production w1ll be identical to that for the shift/methanation reaction system. The lnvestment cost and operating cost for hydrogen production is expected to increase slightly due to the increased $\mathrm{CO}_{2}$ removal requirement. 


\subsection{LITERATURE REFERENCES}

(1) GRI-83/0003, "Guidelines for Evaluation of Commerclal Fossil Fuel Gasification Concepts - 1986 Revision" by F. M. Floyd and R. E. Dillon (March 1986).

(2) GRI-87/0160, Toplcal Report "Des1gn and Economlcs of Plants to Convert Eastern Bltuminous Coal to Methane Using KRW Gasiflers", Fluor Technology Inc. (January 1987).

(3) Advanced Studies of the Blological Conversion of Coal Synthes1s Gas to Methane, Toplcal Report on Task 5 - Mass Transfer and Kinetic Studies, University of Arkansas, March 1989, DOE Contract No. DE-AC21-86MC23281.

(4) Advanced Studies of the Blological Conversion of Coal Synthesis Gas to Methane, Draft F1nal Report, University of Arkansas, November 1989, DOE Contract No. DE-AC21-86MC23281.

(5) Advanced Studies of the Blological Conversion of Coal Synthesis Gas to Methane, Topical Report Task 7: Economic Evaluation, University of Arkansas, January 1990, DOE Contract No. DE-AC21-86MC23281. 

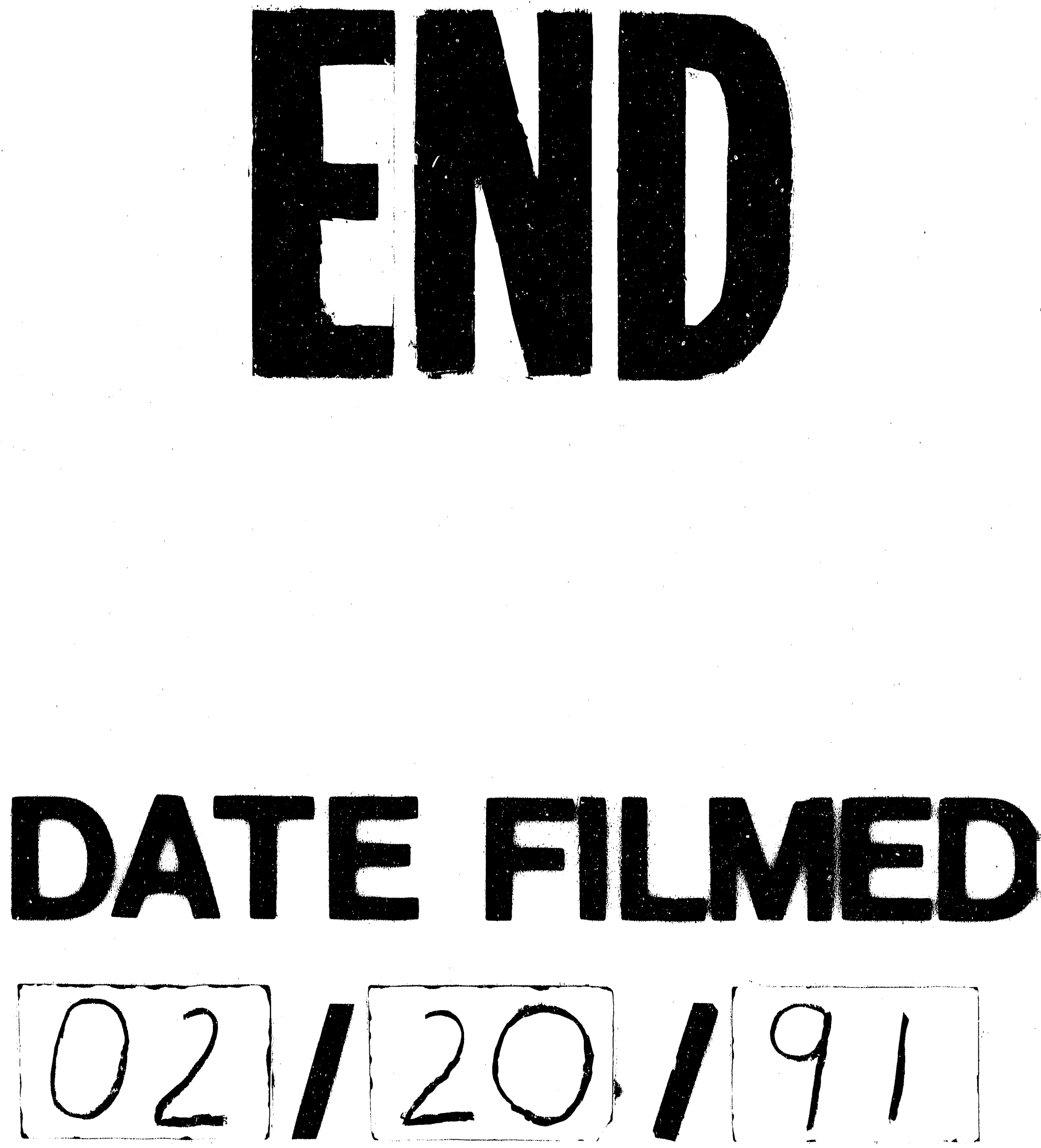